Article

\title{
Rare Earth Elements Geochemistry and C-O Isotope Characteristics of Hydrothermal Calcites: Implications for Fluid-Rock Reaction and Ore-Forming Processes in the Phapon Gold Deposit, NW Laos
}

\author{
Linnan Guo *, Lin Hou, Shusheng Liu and Fei Nie \\ Chengdu Center, China Geological Survey, Chengdu 610081, China; houlin_aaron@163.com (L.H.); \\ lshusheng@cgs.cn (S.L.); niefei_cugb@163.com (F.N.) \\ * Correspondence: linnanguo@163.com; Tel.: +86-028-8232-1057
}

Received: 26 August 2018; Accepted: 6 October 2018; Published: 9 October 2018

check for updates

\begin{abstract}
The Phapon gold deposit is located in the northern Laos and the northern segments of the Luang Prabang-Loei metallogenic belt. The lode-gold orebodies consist of auriferous calcite veins in the middle, and the surrounding siderite alteration and hematite alteration zones in red color. This deposit is hosted in Lower Permian limestone and controlled by a NE-trending ductile-brittle fault system, and it is characterized by the wallrock alteration of carbonatization and lack of quartz and metal sulfides. The hydrothermal calcite from auriferous calcite veins and red alteration zone, as well as the wall rocks of limestone and sandstone were selected for rare earth elements (REE) and C-O isotope analyses. The two types of calcite and limestone have generally consistent REE patterns and $\delta \mathrm{Eu}$ and $\delta \mathrm{Ce}$ values, which are completely different from those of sandstone. Calcites from the auriferous vein show slight light rare earth elements (LREE)-depleted patterns and higher $\mathrm{Tb} / \mathrm{La}$ and $\mathrm{Sm} / \mathrm{Nd}$ ratios than the ones from the red alteration zone with slight LREE-enriched patterns. These values indicate that the calcites from the auriferous veins and the red alteration zones are products of homologous fluids, but the former ones are generally likely to form later than the latter ones. The hydrothermal calcites have $\mathrm{C}-\mathrm{O}$ isotope compositions within the range of marine carbonate, and markedly different from the magmatic or mantle reservoir values. Taking the $\mathrm{Y} / \mathrm{Ho}-\mathrm{La} / \mathrm{Ho}$ and $\mathrm{Tb} / \mathrm{Ca}-\mathrm{Tb} / \mathrm{La}$ variations into consideration, we believe the hydrothermal calcites could be formed from remobilization and recrystallization of the ore-hosted limestone, and the fluid-wallrock interaction played a major role in the gold mineralization in Phapon. In combination with the regional and local geology, the ore-forming process is suspected to be primarily associated with dehydration and decarbonisation of the Lower Permian limestone and Middle-Upper Triassic sandstones. The Phapon gold deposit could have been formed during the Late Triassic-Jurassic regional dynamic metamorphism driven by Indochina-Sibumasu post-collisional magmatism. A number of features in Phapon are similar to epizonal orogenic deposit, but it is still a unique calcite vein type gold deposit in the Luang Prabang-Loei metallogenic belt.
\end{abstract}

Keywords: Rare-Earth Elements; C-O isotopes; hydrothermal calcite; ore-forming processes; Phapon gold deposit

\section{Introduction}

The Phapon gold deposit is a calcite-vein type deposit located in the northern segments of the Luang Prabang-Loei metallogenic belt (Figure 1). This is characterized by multiple generations of arc-related magmatic events and associated copper, gold and other polymetallic deposits [1-5]. The Phapon gold deposit, hosted in the Lower Permian limestone and controlled by a NE-trending 
ductile-brittle fault system, has reached a large scale since it was found in northern Laos in the 1990s [6]. The deposit is characterized by lode-gold orebodies surrounded by carbonatization zones, and absence of quartz and metal sulfides. It is unique compared to the porphyry-related skarn and epithermal systems along the metallogenic belt. Previous studies on Phapon mainly focused on deposit geology [6,7], nature of ore-forming fluids [8], and hydrothermal alteration [9]. Some researchers, based on individual hydrogen and oxygen isotopic data, suggested that the ore-forming fluids derived from deep-seated magmatic water mixed with shallower meteoric water during mineralization $[10,11]$. On the other hand, microstructural studies by Li et al. [12] and Yang et al. [13] argued that the ore-forming fluids were sourced from pressure dissolution in shear dynamic metamorphism. Comprehensive studies on deposit geology, ore-controlling structures, and ore deposit geochemistry suggested the Phapon deposit is a shear zone-controlled low-temperature hydrothermal deposit $[14,15]$. However, there is little detailed study on the genetic relations between hydrothermal calcite and wall rocks, or the relationships between the origin of the Phapon gold deposit and the regional geotectonic evolution and magmatic events. The ore-forming processes, as a result, still remain controversial.

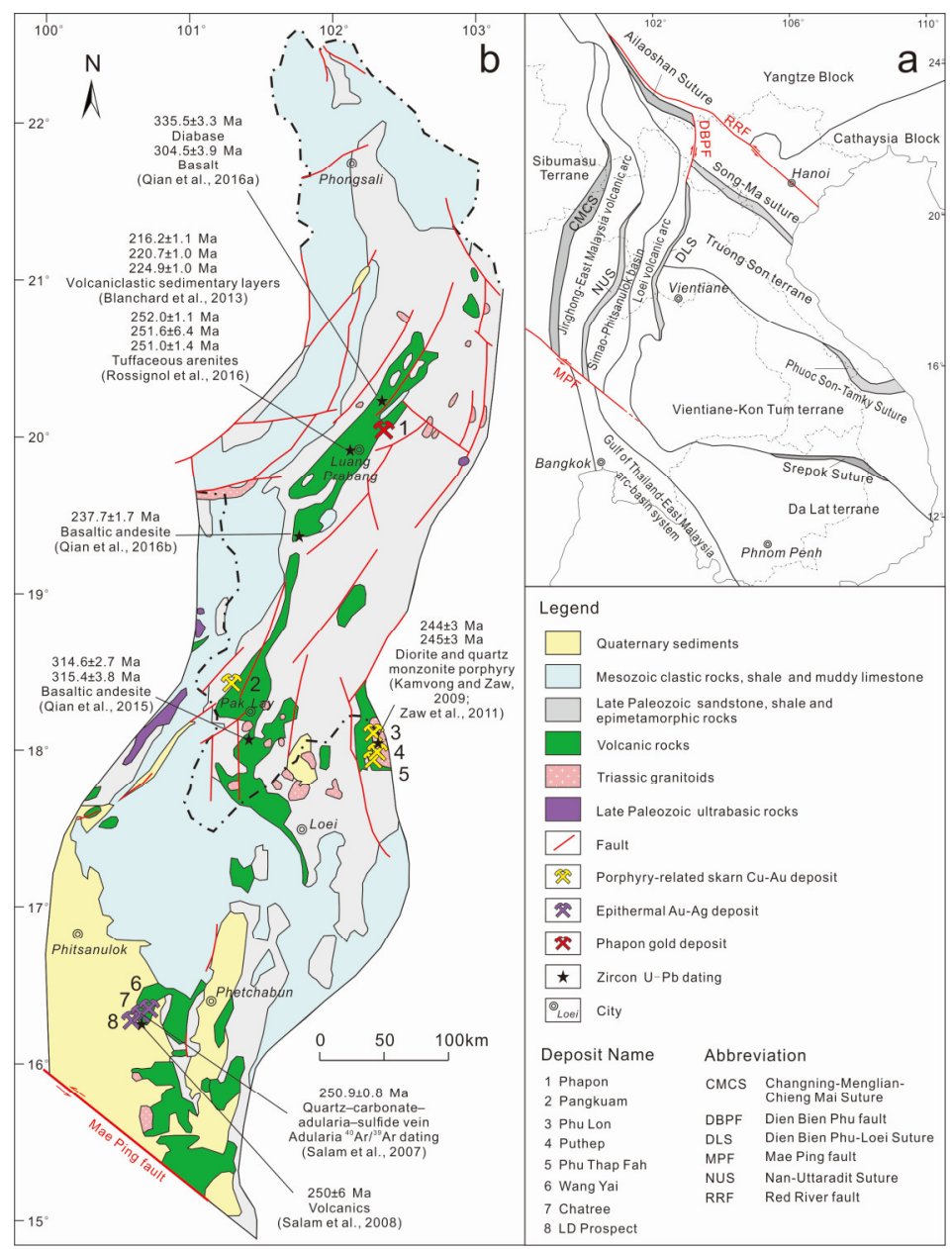

Figure 1. Regional geological map. (a) Simplified tectonic map showing structural units of Laos and adjacent regions [4,16]; (b) Simplified geological map of the Luang Prabang-Loei metallogenic belt (modified from [5]). RRF, Red River fault; DBPF, Dien Bien Phu fault; MPF, Mae Ping fault; CMCS, Changning-Menglian-Chieng Mai Suture; NUS, Nan-Uttaradit Suture; DLS, Dien Bien Phu-Loei Suture.

Rare earth elements (REE) generally migrate together during geological processes, but they have slightly different geochemical behaviors due to nuances of ionic radius and electronic configuration $[17,18]$; thus, REE usually contain important geochemical information [19] and have 
now become a powerful tool for geochemical research in hydrothermal deposits [20]. Previous studies indicated that $\mathrm{REE}^{3+}$ can go into the mineral lattice by replacement of $\mathrm{Ca}^{2+}[21,22]$, so calcium-bearing minerals usually have a strong holding capacity for REE [23]. The REE composition and distribution patterns of hydrothermal Ca-bearing minerals are, at present, widely used to trace ore-forming fluids and ore-forming process of hydrothermal deposits (e.g., Bau et al.; Zhang et al.; Wang et al.; Wu et al.; Cao et al. [24-28]). In this study, we carried out detailed field work, and REE and C-O isotope geochemistry analyses, to indicate genetic relationships of the hydrothermal calcites and limestone wallrock, to define the source of ore-forming fluids, and to discuss the ore-forming processes in the Phapon gold deposit.

\section{Regional Geology}

The Luang Prabang-Loei metallogenic belt, lies along the western periphery of the Indochina Terrane, is one of the important copper-gold-silver polymetallic metallogenic belts in East Tethys metallogenic region [29-31] (Figure 1a). The metallogenic belt is bounded to the west by the Nan-Uttaradit Suture and to the east by the Dien Bien Phu-Loei Suture, with a length of $\sim 800 \mathrm{~km}$ from north to south and a width of $\sim 200 \mathrm{~km}$ from east to west. The belt extends from northern Laos to central-northern Thailand (Figure 1b), which can be divided into the eastern Loei volcanic arc and Simao-Phitsanulok basin in the west (Figure 1a).

The Loei volcanic arc is distributed parallel with the Dien Bien Phu-Loei Suture on the east side (Figure 1a). It developed a Late Carboniferous-Middle Triassic island arc calc-alkaline series, with volcanic rocks ranging from basic to neutral to acidic [32]. It contains multiple generations of successive arc-related magmatic events, which separated by periods of exhumation and erosion [33]. The Carboniferous sedimentary sequence, consisting of clastic rocks, carbonate rocks and volcanic rocks, is overlain by thick middle Permian limestone marked by basal conglomerate, siltstone and shale [34,35].

The Simao-Phitsanulok basin is located to the east of the Nan-Uttaradit Suture (Figure 1a). It is an intracontinental basin formed during the basin-to-mountain transition from late Permian to early Triassic, after the Nan-Uttaradit back-arc ocean basin closed, and showed foreland basin in nature in middle-late Triassic. The basin is mainly composed of upper Triassic coal-bearing sandstone, shale, marl, conglomerate, and tuff sandstone, belonging to continental molasse deposits of the foreland basin, and Jurassic-Cretaceous continental clastic rock series, consist of siltstone, sandstone, shale, and marl [16] (Figure 1b).

Three main periods of volcanism have been identified based on zircon U-Pb ages, which can be divided into Carboniferous, late Permian to early Triassic, and middle-late Triassic (Figure 1b). Previous studies showed that the Carboniferous volcanic rocks of the Loei volcanic arc are widespread from Luang Prabang to Pak Lay in Laos [36,37]. The Late Permian to Early Triassic volcanic rocks are exposure around Luang Prabang [38], and to the west of Phetchabun [33]. The Middle-Late Triassic volcanic rocks are confined to the southwest of Luang Prabang [39], or around Luang Prabang [40]. The intrusive rocks, dominated by Triassic island arc I-type granitoids [32,41], are normally distributed to the northeast of Luang Prabang and around Pak Lay in Laos, and in Loei Province of Thailand.

The Luang Prabang-Loei metallogenic belt is dominated by porphyry-related skarn type copper-gold deposits, and epithermal gold-silver deposits (Table 1; Figure 1b). The former ones are associated with the Early-Middle Triassic subalkalic to calc-alkaline quartz monzonite and diorite-monzodiorite (granodiorite) porphyry [42,43], while the later ones are associated with Early Permian to Late Triassic andesitic to rhyolitic volcanic/volcaniclastic units [44,45]. The Phapon gold deposit, nevertheless, shows significant differences from the above skarn or epithermal-type gold deposits (e.g., Qiu et al. [46,47]), including ore-forming environment, wall rock alteration, mineralization style, and mineral assemblage (Table 1). Thus, it can be regarded as a unique type of gold deposit in the Luang Prabang-Loei metallogenic belt, named calcite vein type gold deposit. 
Table 1. Basic information of major gold deposits in the Luang Prabang-Loei metallogenic belt (collated from Zaw et al., 2014; Zhao et al., 2017) [3,44].

\begin{tabular}{|c|c|c|c|c|c|c|c|}
\hline $\begin{array}{l}\text { No. in } \\
\text { Map }\end{array}$ & Deposit & Deposit Type & Tonnage (Mt) & Grade & Host Rocks & Intrusions/Ages & Alteration Minerals \\
\hline 1 & Phapon (Au) & Calcite vein-type & No data & $6.28 \mathrm{~g} / \mathrm{t} \mathrm{Au}$ & Limestone & No known intrusion & $\begin{array}{l}\text { Calcite, siderite, } \\
\text { magnitite, realgar }\end{array}$ \\
\hline 2 & $\begin{array}{l}\text { Pangkuam } \\
(\mathrm{Cu}-\mathrm{Au})\end{array}$ & $\begin{array}{l}\text { Porphyry-related } \\
\text { skarn }\end{array}$ & No data & $\begin{array}{c}0.69 \% \mathrm{Cu} \\
2.41 \mathrm{~g} / \mathrm{t} \mathrm{Au}\end{array}$ & $\begin{array}{c}\text { Limestone, } \\
\text { argillaceous siltstone }\end{array}$ & Intermediate-mafic intrusions & $\begin{array}{c}\text { Quartz, sericite, epidote, } \\
\text { chlorite, K-feldspar, garnet }\end{array}$ \\
\hline 3 & $\begin{array}{l}\text { Phu Lon } \\
(\mathrm{Cu}-\mathrm{Au})\end{array}$ & $\begin{array}{l}\text { Porphyry-related } \\
\text { skarn }\end{array}$ & 5.4 & $\begin{array}{c}2.4 \% \mathrm{Cu} \\
0.64 \mathrm{~g} / \mathrm{t} \mathrm{Au}\end{array}$ & $\begin{array}{l}\text { Limestone, } \\
\text { volcaniclastics }\end{array}$ & $\begin{array}{c}\text { Diorite and quartz monzonite } \\
\text { porphyry/244 } \pm 3 \mathrm{Ma}\end{array}$ & $\begin{array}{c}\text { Garnet, pyroxene, } \\
\text { K-feldspar, tremolite, } \\
\text { epidote, chlorite, calcite }\end{array}$ \\
\hline 4 & $\begin{array}{l}\text { Puthep } \\
(\mathrm{Cu}-\mathrm{Au})\end{array}$ & $\begin{array}{l}\text { Porphyry-related } \\
\text { skarn }\end{array}$ & 164 & $\begin{array}{c}0.53 \% \mathrm{Cu} \\
0.09 \mathrm{~g} / \mathrm{t} \mathrm{Au}\end{array}$ & $\begin{array}{l}\text { Sandstone, siltstone } \\
\text { and sandstone }\end{array}$ & $\begin{array}{l}\text { Diorite and monzodiorite } \\
\text { porphyry/242.4 } \pm 1.3 \mathrm{Ma}\end{array}$ & $\begin{array}{l}\text { K-feldspar, sericite, garnet, } \\
\text { epidote, chlorite, calcite }\end{array}$ \\
\hline 5 & $\begin{array}{l}\text { Phu Thap Fah } \\
(\mathrm{Cu}-\mathrm{Au}-\mathrm{Ag})\end{array}$ & Skarn & 6.4 & $\begin{array}{l}0.14 \% \mathrm{Cu}, \\
2.19 \mathrm{~g} / \mathrm{t} \mathrm{Au} \\
3.9 \mathrm{~g} / \mathrm{t} \mathrm{Ag}\end{array}$ & $\begin{array}{l}\text { Siliciclastics and } \\
\text { limestone }\end{array}$ & Granodiorite/245 $\pm 3 \mathrm{Ma}$ & $\begin{array}{l}\text { garnet, pyroxene, quartz, } \\
\text { epidote, calcite, chlorite }\end{array}$ \\
\hline 6 & $\begin{array}{l}\text { Wang Yai } \\
(\mathrm{Au}-\mathrm{Ag})\end{array}$ & Low-S epithermal & No data & No data & $\begin{array}{l}\text { Volcaniclastics, } \\
\text { rhyolite breccia }\end{array}$ & No known intrusion & $\begin{array}{l}\text { Quartz, calcite, adularia, } \\
\text { sericite, chlorite }\end{array}$ \\
\hline 7 & $\begin{array}{l}\text { Chatree } \\
(\mathrm{Au}-\mathrm{Ag})\end{array}$ & Low-S epithermal & 81.7 & $\begin{array}{l}1.18 \mathrm{~g} / \mathrm{t} \mathrm{Au} \\
9 \mathrm{~g} / \mathrm{t} \mathrm{Ag}\end{array}$ & $\begin{array}{l}\text { Andesite breccias, } \\
\text { volcanogenic } \\
\text { sedimentary rocks }\end{array}$ & $\begin{array}{c}\text { Diorite dyke and } \\
\text { granodiorite-bearing basaltic } \\
\text { dyke/244 } \pm 7 \mathrm{Ma}\end{array}$ & $\begin{array}{l}\text { Quartz, calcite, adularia, } \\
\text { sericite, chlorite, } \\
\text { illite, smectite } \\
\end{array}$ \\
\hline 8 & $\begin{array}{l}\text { LD Prospect } \\
(\mathrm{Au}-\mathrm{Ag})\end{array}$ & Low-S epithermal & 2.9 & $\begin{array}{l}1.1 \mathrm{~g} / \mathrm{t} \mathrm{Au} \\
10 \mathrm{~g} / \mathrm{t} \mathrm{Ag}\end{array}$ & Andesite & No known intrusion & $\begin{array}{l}\text { Quartz, pyrite, calcite, } \\
\text { adularia, sericite, chlorite }\end{array}$ \\
\hline
\end{tabular}




\section{Local Geology}

\subsection{Ore Deposit Geology}

The Phapon gold deposit is located about $30 \mathrm{~km}$ northeast to the Luang Prabang (Figure 1b). The exposed strata around the mining area are mainly Carboniferous, Lower-Middle Permian, Middle-Upper Triassic and Quaternary (Figure 2). Carboniferous sedimentary formation consists of mottled sandstone, siltstone, mudstone, gray-black claystone and limestone with banded chert. Strong ductile shearing occurred during the Variscan orogeny, showing obvious plastic flow in the carboniferous rock. The main lithology of the Lower Permian is thick layer microcrystalline limestone and bioclastic limestone with marlstone and siltstone at the bottom. The limestone masses occur as a lens which strikes $35-50^{\circ}$ and dips $15-45^{\circ}$ towards the NE, and show strong ductile-brittle shear deformation in the ore-bearing section. The Upper Permian is composed of gray-green andesite, andesitic tuff and basalt, and show unconformable or fault contact relationship with the underlying strata. The Middle-Upper Triassic extends northeast in the mining area and it consists mainly of purplish-red conglomerate, sandstone, siltstone and feldspar sandstone, representing dry and oxidizing deposition in the foreland basin and intermountain basin. The Quaternary is mainly composed of residual red clay, with discontinuous distribution. The area is lenticular in shape with locally distributed epigenetic lateritic gold deposits. There is no large intrusive rock mass in the mining area, except for effusive-facies volcanic rocks exposed in the northwestern part. Its lithology contains mainly andesite and andesitic tuff, with locally diabase and dioritic porphyrite. The andesite is cryptocrystalline with few phenocrysts, and is gray-green in color, showing weak propylitization.

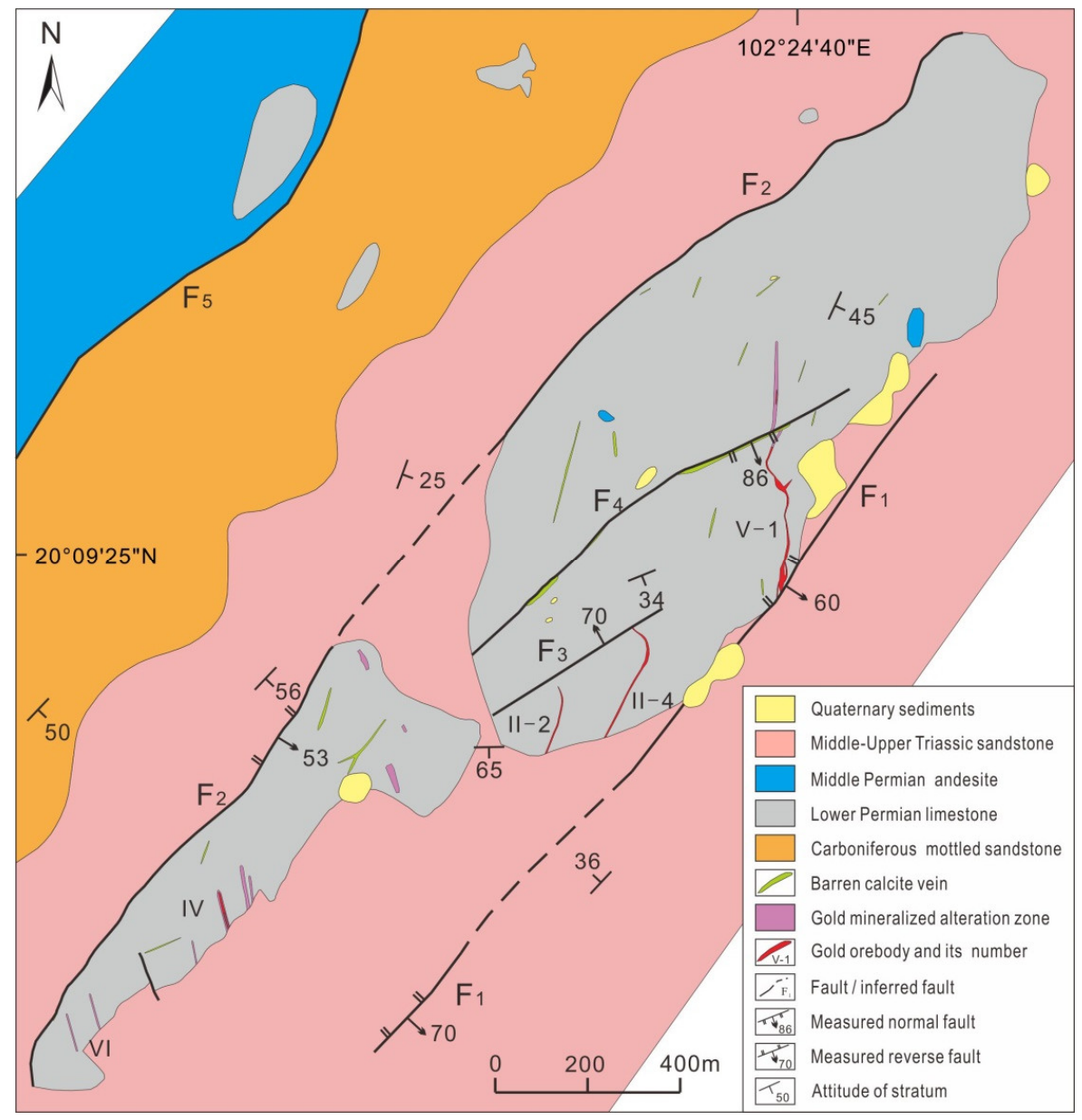

Figure 2. Sketch map of the Phapon gold deposit [13]. 
The structures in the mining area are mainly characterized by NE-trending ductile-brittle shear zones and brittle faults in different directions [13] (Figure 2). The NE-trending Luang Prabang ductile-brittle shear zone runs through the whole area and has a width of several hundred meters with multi-stage activities. The ductile-brittle shear zone developed during the early stage of Carboniferous and was dominated by ductile deformation. It developed strong plastic deformation including strong mylonitization, plasticity rheology, sheath fold, book slant tectonics and pyrite stress shadow during the Variscan orogeny. In the late stage, the reactivation Luang Prabang ductile-brittle shear zone in the Upper Permian limestone led to secondary faults with different orientations and controlled the NE-zonal distributed gold mineralization.

The main brittle faults in the mining area can be divided into NE-trending and NNW-trending groups, and the latter group is the main ore-controlling structure of the Phapon gold deposit. The NE-trending faults are well developed with multi-period activities, including $F_{1}, F_{2}, F_{3}, F_{4}$, and $F_{5}$ fault (Figure 2). The $F_{1}$ and $F_{2}$ are compressive-torsional reverse faults and along the contact zones of the Lower Permian limestone and the Middle-Upper Triassic sandstone on the southeast and northwest sides, respectively. It is marked by crushing limestone with carbonatization and calcite veins, showing a post-mineralization feature. The ore-hosting Lower Permian limestone overlay the Middle-Upper Triassic sandstone, and the ore-hosting limestone show differences in lithofacies with the local Lower Permian limestone. This infers a thrust nappe structure and the main thrust planes is the $F_{2}$ fault (Figure 2). The limestone along the thrust zone is generally broken. Compare to the more ductile argillaceous limestone, the sandy limestone appears relatively brittle, and normally show ductile deformation such as boudinage (Figure 3a). Schistosity zones and mylonitic lens also exist near the thrust plane (Figure $3 b$ ).
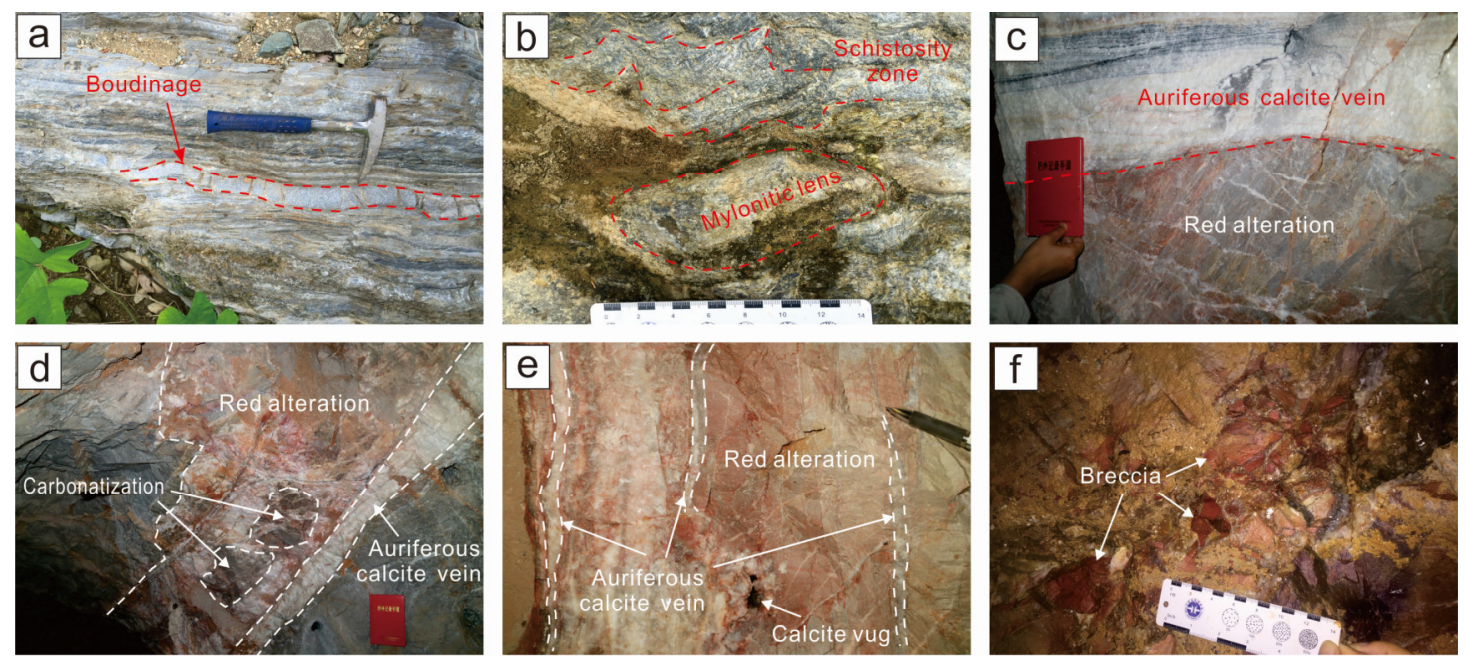

Figure 3. Typical outcrops of deformation, alteration and mineralization in Phapon gold deposit. (a) Boudinage deformation found in limestone; (b) schistosity zones and mylonitic lens near the thrust plane; (c) auriferous calcite vein and surrounding red alteration zone; (d) carbonation clumps locally present in the red alteration zone; (e) calcite veins branched and intercalated into the red alteration zone; (f) breccia of red altered rock.

There are five orebodies found in the Phapon gold deposit, which from east to west are No. V-1, II-4, II-2, IV, and VI, respectively (Figure 2). These vein-shaped orebodies are subparallel with a spacing of about $\sim 300 \mathrm{~m}$, and controlled from east to west by a series of NNW-trending faults. They generally vary from 300 to $800 \mathrm{~m}$ in length, 1 to $10 \mathrm{~m}$ in width, and strike $330-350^{\circ}$ and dip $45-65^{\circ}$ towards the SWW (Figure 2). The No. V-1 orebody, which comprises more than $90 \%$ of the proven reserves in the Phapon deposit, shows typical vein-shaped and locally cystic or lenticular-shaped orebodies. It is approximately $650 \mathrm{~m}$ long, generally strikes $330-355^{\circ}$, and dips $40-50^{\circ} \mathrm{SW}$ with large variation locally. It ranges in thickness from 0.3 to $10 \mathrm{~m}$, averaging approximately $3.4 \mathrm{~m}$, and extends down-dip 
approximately $350 \mathrm{~m}$. The thickness of the orebody and the ore type change with its occurrence, and the average gold grade is $6.28 \mathrm{~g} / \mathrm{t}$.

\subsection{Alteration and Mineralization}

The hydrothermal alteration at Phapon developed in the lower Permian limestone and is controlled by the NNW-trending fault zones. It is characterized by medium-low temperature alteration including carbonation, siderite alteration, magnetite alteration, hematite alteration, and silicification, and shows macroscopic red-color alteration and light gray-color carbonation (Figure 3c-e). The red-color alteration is mainly caused by siderite and hematite alteration that infiltrate the surrounding limestone. It extends from centimeters to several meters along the ore-bearing faults (Figure 3c). It has a close relationship with gold mineralization and it represents a special alteration in the area. Siderite and hematite are normally distributed as disseminations, orlocally fill micro fractures in limestone (Figure $4 \mathrm{~d}, \mathrm{e}$ ). Carbonation occurred mainly as planar alteration, which is characterized by the in situ dissolution and recrystallization of limestone and the formation of fine calcite grains, showing pale in color from the surrounding limestone (Figure 3d). Carbonation spread outside of the red-color alteration and is one of the main alteration of the deposit. The silicification is normally weak and intergrown with carbonation, and the anhedral quartz is distributed as disseminations in the wallrock. The alteration strength is weakened from the center and to the two sides of the fault zone. It mainly consists of a narrow proximal zone of red alteration, and a wide outer zone of carbonation (Figure 3d). In some cases, carbonation clumps locally existed in the red alteration zone (Figure 3d), and the calcite veins branched and intercalated into the red alteration zone (Figure 3e).
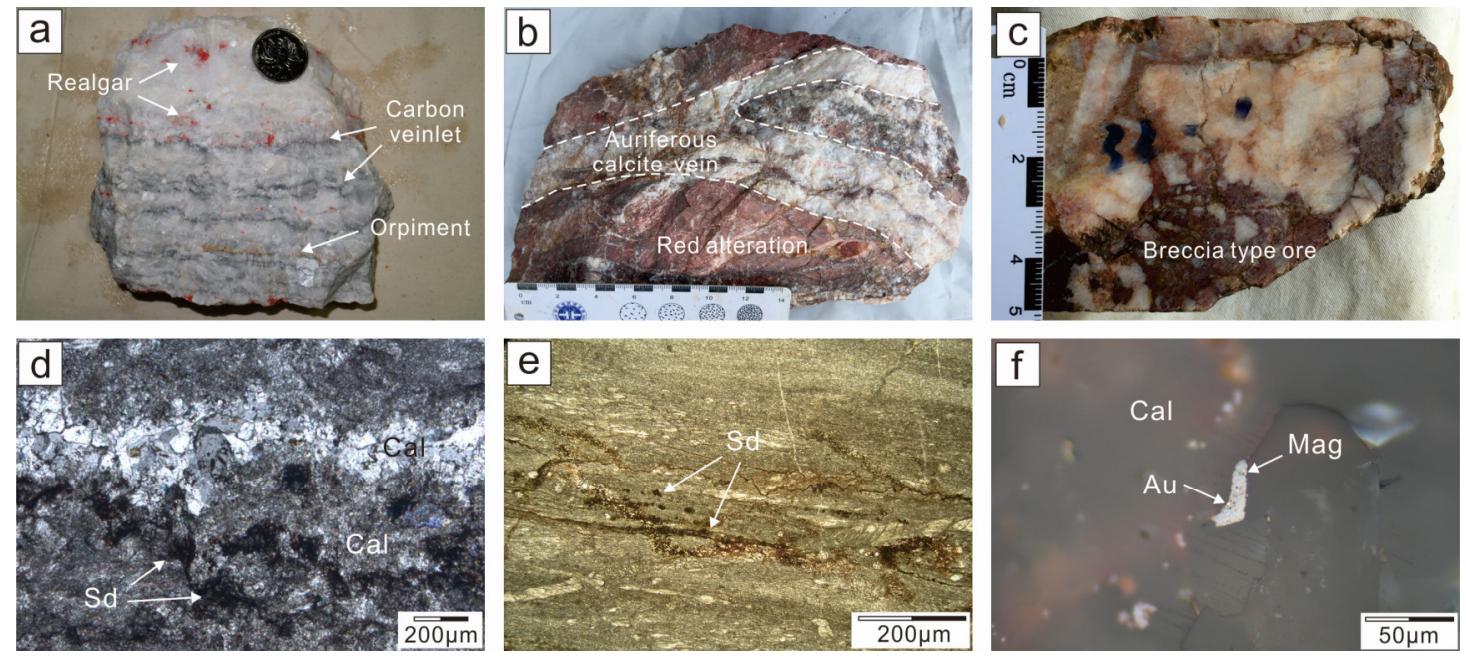

Figure 4. Hand samples and microscopic photographs of typical ores in Phapon gold deposit. (a) Auriferous calcite veins filled with dark-colored carbon layers and red alteration veinlets; (b) red alteration with calcite veinlets; (c) breccia type ore; (d) calcite veinlet in limestone; (e) visible siderite disseminated in limestone; (f) native gold together with magnetite appears as fine disseminations in calcite. Au, gold; Cal, calcite; Mag, magnetite; Sd, siderite.

There are three types of primary ore in the Phapon gold deposit: auriferous calcite vein type (Figure $4 \mathrm{a}$ ), the red altered rock type (Figure $4 \mathrm{~b}$ ), and breccia type (Figures $3 \mathrm{f}$ and $4 \mathrm{c}$ ). The auriferous calcite veins filled the NNW-trending tensile fractures and are dominated by grey-white calcite and in place dark-colored carbon veinlets (Figure 4a). The red altered ores occurred in red alteration zone (Figure 4c). The breccia type ore locally developed on one side of the calcite veins, and the breccia includes red altered limestone (Figure $3 \mathrm{f}$ ) and auriferous calcite veins (Figure $4 \mathrm{c}$ ), whereas the cements are carbonate minerals such as calcite and siderite. The breccia type gold ore has higher gold grade, with gold minerals in both breccia and cements. The ores from the red alteration zone 
generally have high gold grade, and their gold grade has a positive correlation with the strength of the alteration. The auriferous calcite vein type ore has a large variable range, but generally lower gold grade. The coarser the grains of calcite are, the lower the gold grade. The auriferous calcite vein type and red altered rock type ores are the two main ore types in Phapon.

Mineral paragenesis and mineralization stages are difficult to define and remain controversial. It is generally believed the auriferous calcite vein type and red altered rock-type ores formed in the same metallogenic event and through similar gold-deposition processes. The calcite veins normally show crosscutting, variation of calcite sizes (including miarolitic calcite, Figure 3e), or filled with dark-colored carbon veinlets (Figure 4a), indicating a characteristic of muti-stage mineralization. The ore minerals are mainly siderite, magnetite, and hematite, with minor native gold. The gangue minerals are mainly calcite with minor realgar, orpiment and quartz (Figure 4), and the realgar and orpiment are only found in the calcite veins. Calcite is the main gold-bearing mineral. Native gold appears as fine disseminations or in microfractures in calcite (Figure 4f).

\section{Sampling and Analytical Methods}

A total of seventeen typical samples were collected for this study. Calcite grains from auriferous calcite vein type ores (4 samples) and red altered rock type ores (4 samples), and the ore-hosting limestone (7 samples) and the surrounding sandstone (2 samples) were selected for trace element analyses. Except the sandstone, the other 15 samples were also used for carbon and oxygen isotope analyses. The ore hand samples were crushed to 40-60 mesh for mineral separation. Calcite grains were handpicked under a binocular microscope to achieve $>99 \%$ purity. All the analyses were performed at the Analytical Laboratory of the Beijing Research Institute of Uranium Geology, Beijing, China.

\subsection{Trace Element Analyses}

The pure hydrothermal calcite grains and the limestone and sandstone samples were crushed to 200 meshes, and were dissolved in a Teflon bomb using a mixture of $\mathrm{HF}(1 \mathrm{~mL})$ and $\mathrm{HNO}_{3}(1 \mathrm{~mL})$. Then the sealed Teflon bomb was heated at $190{ }^{\circ} \mathrm{C}$ for more than $12 \mathrm{~h}$. The dried sample was refluxed with $30 \% \mathrm{HNO}_{3}(1 \mathrm{~mL})$ and heated in the sealed Teflon bomb again at $190{ }^{\circ} \mathrm{C}$ for another $12 \mathrm{~h}$ with mixture of $\mathrm{HNO}_{3}(1 \mathrm{~mL}), \mathrm{MQ}$ water $(1 \mathrm{~mL})$ and internal standard $\mathrm{In}$. The sample solution was then diluted to $100 \mathrm{~g}$ with $2 \% \mathrm{HNO}_{3}$ in a polyethylene bottle, and measured using an Inductively Coupled Plasma-Mass Spectrometry (ICP-MS) (Agilent 7700e). Detailed operating conditions of the ICP-MS instrument and data reduction processes have been described by Liu et al. [48].

\subsection{C-O Isotope Analyses}

Both calcite grains from ores and ore-hosting limestone samples were crushed to 200 meshes, and water was released from the carbonate sample by heating to $105^{\circ} \mathrm{C}$ for $2 \mathrm{~h}$ in an oven. The dried samples then reacted with phosphoric acid to produce $\mathrm{CO}_{2}$, and $\mathrm{CO}_{2}$ was then measured for $\mathrm{C}$ and $\mathrm{O}$ isotopic composition by a MAT-253 mass spectrometer. The $\mathrm{C}$ and $\mathrm{O}$ isotope analysis results adopted the Pee Dee Belemnite (PDB) and Standard Mean Ocean Water (SMOW) standards, respectively, with a precision of $\pm 0.1 \%$ ofor $\delta^{13} \mathrm{C}$, and $\pm 0.2 \%$ for $\delta^{18} \mathrm{O}$ [49].

\section{Analytical Results}

\subsection{Rare Earth Elements}

The concentrations of REE for calcites, limestone and sandstone are presented in Table 2, and displayed in Figure 5. The calcites from the auriferous calcite vein type ores contain relatively low total REE abundances ( $\Sigma R E E=1.50-4.98 \mathrm{ppm}$, average of $2.67 \mathrm{ppm}$ ), and show heavy rare earth elements (HREE) flat patterns (Figure 5a). The LREE/HREE ratios vary from 0.88 to 1.89, with an average of 1.25. Eu is slightly depleted with $\delta \mathrm{Eu}$ ranges between 0.69 and 0.81 (average of 0.77 ), and Ce is distinctively depleted with $\delta$ Ce ranges between 0.35 and 0.46 (average of 0.39 ). 
All calcite samples contain relatively low $\mathrm{Y}$ content (2.14-7.55 ppm), with identical $\mathrm{Y} / \mathrm{Ho}$ ratios (40.2-49.6). The calcites from red altered rock type ores have similar REE pattern with the vein-type ones (Figure 5a). They contain relatively higher total REE abundances $(\Sigma R E E=3.69-7.57 \mathrm{ppm}$, average of $2.67 \mathrm{ppm}), \mathrm{Y}$ content (4.88-10 ppm) and Y/Ho ratios (52.3-61.0). They have constant LREE/HREE ratios varying from 1.68 to 1.80 with an average of 1.75 . The Eu and Ce anomalies are somewhat stronger $(\delta \mathrm{Eu}=0.61-0.71$ and $\delta \mathrm{Ce}=0.33-0.38)$.
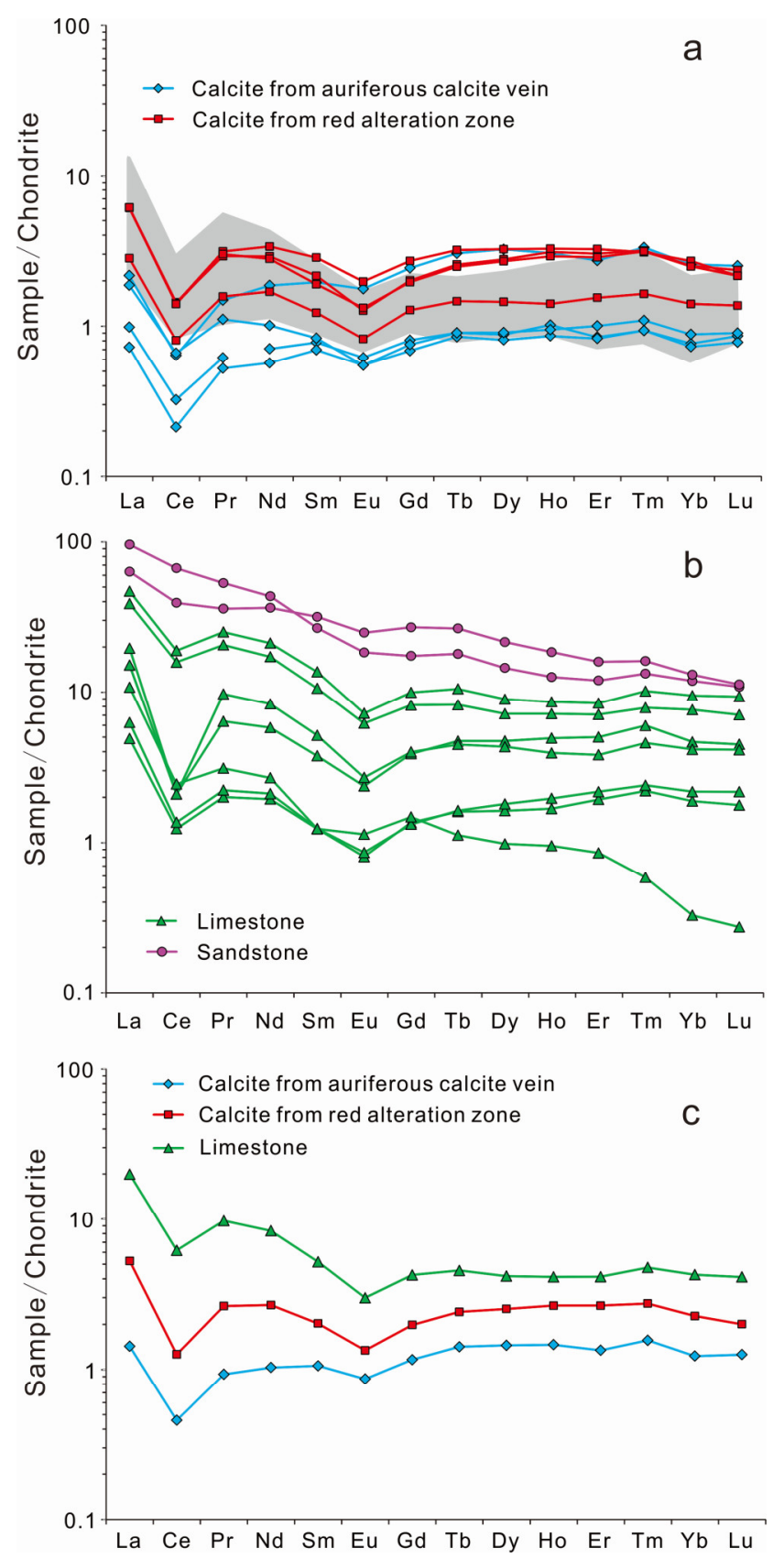

Figure 5. Rare Earth Elements (REE) distribution patterns of hydrothermal calcite and country rocks in Phapon. All samples are normalized to chondrite [50]. (a) Calcites respective from auriferous calcite vein and red alteration zone, shadow area referenced from [11]; (b) limestone and sandstone; (c) average value of two types of calcite and limestone. 
Table 2. Trace element and REE concentrations $\left(\times 10^{-6}\right)$ in calcite, limestone and sandstone from the Phapon deposit.

\begin{tabular}{|c|c|c|c|c|c|c|c|c|c|c|c|c|c|c|c|c|c|}
\hline \multirow[b]{2}{*}{ Sample } & \multicolumn{4}{|c|}{ Calcite from Auriferous Calcite Vein } & \multicolumn{4}{|c|}{ Calcite from Red Alteration Zone } & \multicolumn{7}{|c|}{ Limestone } & \multicolumn{2}{|c|}{ Sandstone } \\
\hline & $\begin{array}{c}\text { PB- } \\
\text { PDB04-1 }\end{array}$ & $\begin{array}{c}\text { PB- } \\
\text { PDB04-2 }\end{array}$ & $\begin{array}{c}\text { PB- } \\
\text { PDB04-3 }\end{array}$ & $\begin{array}{c}\text { PB- } \\
\text { ZKB04 }\end{array}$ & $\begin{array}{c}\text { PB- } \\
\text { ZKB05-1 }\end{array}$ & $\begin{array}{c}\text { PB- } \\
\text { ZKB05-2 }\end{array}$ & $\begin{array}{c}\text { PB- } \\
\text { ZKB05-3 }\end{array}$ & $\begin{array}{c}\text { PB- } \\
\text { ZKB05-4 }\end{array}$ & $\begin{array}{c}\text { PB- } \\
\text { PDB03 }\end{array}$ & $\begin{array}{c}\text { PB- } \\
\text { PDB05-1 }\end{array}$ & $\begin{array}{c}\text { PB- } \\
\text { PDB05-2 }\end{array}$ & $\begin{array}{c}\text { PB- } \\
\text { B01-1 }\end{array}$ & $\begin{array}{c}\text { PB- } \\
\text { B01-2 }\end{array}$ & $\begin{array}{c}\text { PB- } \\
\text { ZKB02-1 }\end{array}$ & $\begin{array}{c}\text { PB- } \\
\text { ZKB02-2 }\end{array}$ & $\begin{array}{c}\text { PB- } \\
\text { PDB06 }\end{array}$ & $\begin{array}{c}\text { PB- } \\
\text { ZKB01 }\end{array}$ \\
\hline $\mathrm{Li}$ & $<0.002$ & $<0.002$ & $<0.002$ & $<0.002$ & $<0.002$ & $<0.002$ & $<0.002$ & $<0.002$ & 2.02 & 2.24 & 1.89 & 5.28 & 5.76 & 1.82 & 2.18 & 23.6 & 38 \\
\hline $\mathrm{Be}$ & 0.017 & 0.002 & 0.024 & 0.005 & $<0.002$ & 0.025 & $<0.002$ & 0.033 & 0.085 & 0.036 & 0.061 & 0.431 & 0.348 & 0.063 & 0.022 & 1.53 & 1.19 \\
\hline Sc & 0.431 & 1.05 & 0.469 & 0.509 & 0.469 & 0.48 & 0.949 & 0.581 & 1.03 & 1.05 & 1.13 & 4.31 & 4.12 & 2.16 & 1.06 & 14.4 & 4.65 \\
\hline $\mathrm{V}$ & 1.76 & 5.01 & 1.61 & 1.38 & 1.69 & 1.39 & 3.04 & 1.4 & 3.94 & 5.2 & 6.32 & 25.5 & 23.1 & 7.28 & 2.75 & 103 & 36.5 \\
\hline $\mathrm{Cr}$ & 1.27 & 2.54 & 1.49 & 3.27 & 3.12 & 3.24 & 3.9 & 3.6 & 8.75 & 8.62 & 12.3 & 9.83 & 11.4 & 6.7 & 3.18 & 73 & 20.5 \\
\hline Co & 1.13 & 1.14 & 1.31 & 1.2 & 1.18 & 1.21 & 1.28 & 1.26 & 1.52 & 1.5 & 1.57 & 3 & 3.41 & 1.75 & 1.66 & 14.2 & 4.44 \\
\hline $\mathrm{Ni}$ & 11.8 & 13.7 & 13.5 & 14.3 & 15.3 & 15.1 & 16.6 & 16.3 & 12.2 & 12.6 & 13.2 & 7.62 & 10 & 13.7 & 13 & 17.9 & 15.4 \\
\hline $\mathrm{Cu}$ & 0.057 & 0.099 & 0.061 & 0.149 & 0.026 & 0.196 & 0.104 & 0.024 & 0.585 & 0.429 & 0.474 & 16.5 & 18.2 & 1.61 & 0.207 & 9.08 & 11.6 \\
\hline $\mathrm{Zn}$ & 2.53 & 2.1 & 2.1 & 2.22 & 6.05 & 3.34 & 2.9 & 4.11 & 4.22 & 7.68 & 7.35 & 25.3 & 33.1 & 18.6 & 4.98 & 68.1 & 48.3 \\
\hline $\mathrm{Ga}$ & 0.019 & 0.01 & $<0.002$ & 0.011 & 0.02 & 0.019 & 0.022 & 0.039 & 0.067 & 0.19 & 0.249 & 3.43 & 3.12 & 0.287 & 0.066 & 13.4 & 19.5 \\
\hline $\mathrm{Rb}$ & 0.03 & 0.029 & 0.027 & 0.034 & 0.026 & 0.045 & 0.037 & 0.062 & 0.285 & 0.968 & 1.23 & 21.6 & 18.7 & 1.08 & 0.192 & 23.1 & 45.6 \\
\hline $\mathrm{Sr}$ & 674 & 451 & 686 & 456 & 430 & 376 & 485 & 398 & 181 & 401 & 409 & 777 & 965 & 207 & 452 & 400 & 106 \\
\hline Y & 2.33 & 7.55 & 2.14 & 2.68 & 4.88 & 10 & 9.67 & 9.47 & 12.1 & 6.07 & 6.42 & 13.9 & 16.3 & 8.72 & 4.62 & 20.1 & 41.7 \\
\hline Mo & $<0.002$ & $<0.002$ & $<0.002$ & $<0.002$ & $<0.002$ & $<0.002$ & $<0.002$ & $<0.002$ & $<0.002$ & 0.032 & 0.037 & 0.283 & 0.258 & 0.008 & $<0.002$ & 0.284 & 0.193 \\
\hline $\mathrm{Cd}$ & 0.01 & 0.009 & 0.036 & 0.175 & 0.013 & 0.056 & 0.076 & 0.025 & 0.573 & 0.418 & 0.383 & 0.2 & 0.247 & 1.28 & 0.088 & 0.22 & 0.617 \\
\hline In & $<0.002$ & 0.002 & $<0.002$ & 0.002 & $<0.002$ & 0.003 & 0.005 & 0.003 & $<0.002$ & 0.004 & 0.005 & 0.017 & 0.018 & $<0.002$ & $<0.002$ & 0.058 & 0.016 \\
\hline $\mathrm{Sb}$ & 0.028 & 0.012 & 0.038 & 0.055 & 0.04 & 0.04 & 0.051 & 0.053 & 0.369 & 0.206 & 0.301 & 0.622 & 0.737 & 0.569 & 0.128 & 0.65 & 0.613 \\
\hline Cs & 0.011 & 0.011 & 0.012 & 0.018 & 0.012 & 0.013 & 0.012 & 0.025 & 0.022 & 0.058 & 0.057 & 1.06 & 0.98 & 0.194 & 0.027 & 1.03 & 10.1 \\
\hline $\mathrm{Ba}$ & 4.25 & 2.59 & 3.75 & 3.83 & 3.07 & 7.67 & 3.79 & 7.7 & 6.98 & 5.78 & 5.87 & 458 & 401 & 10.2 & 3.37 & 153 & 185 \\
\hline $\mathrm{La}$ & 0.235 & 0.515 & 0.173 & 0.444 & 0.671 & 1.45 & 1.44 & 1.45 & 3.54 & 1.15 & 1.47 & 9.03 & 10.9 & 4.58 & 2.52 & 22.2 & 14.7 \\
\hline $\mathrm{Ce}$ & 0.199 & 0.393 & 0.131 & 0.408 & 0.495 & 0.885 & 0.875 & 0.864 & 1.28 & 0.757 & 0.835 & 9.54 & 11.4 & 1.28 & 1.49 & 40 & 23.6 \\
\hline $\operatorname{Pr}$ & 0.059 & 0.142 & 0.05 & 0.106 & 0.15 & 0.277 & 0.298 & 0.286 & 0.6 & 0.19 & 0.211 & 1.93 & 2.35 & 0.911 & 0.294 & 4.95 & 3.35 \\
\hline $\mathrm{Nd}$ & 0.332 & 0.873 & 0.267 & 0.475 & 0.794 & 1.36 & 1.58 & 1.31 & 2.68 & 0.905 & 0.983 & 7.91 & 9.74 & 3.84 & 1.25 & 19.9 & 16.7 \\
\hline $\mathrm{Sm}$ & 0.12 & 0.3 & 0.107 & 0.128 & 0.189 & 0.331 & 0.437 & 0.291 & 0.571 & 0.189 & 0.19 & 1.6 & 2.06 & 0.781 & 0.189 & 4.02 & 4.77 \\
\hline $\mathrm{Eu}$ & 0.036 & 0.103 & 0.032 & 0.032 & 0.048 & 0.074 & 0.115 & 0.077 & 0.137 & 0.047 & 0.05 & 0.355 & 0.413 & 0.156 & 0.066 & 1.05 & 1.42 \\
\hline $\mathrm{Gd}$ & 0.167 & 0.501 & 0.142 & 0.156 & 0.264 & 0.415 & 0.558 & 0.404 & 0.792 & 0.279 & 0.272 & 1.66 & 2.02 & 0.814 & 0.304 & 3.53 & 5.46 \\
\hline $\mathrm{Tb}$ & 0.034 & 0.114 & 0.032 & 0.034 & 0.055 & 0.096 & 0.12 & 0.093 & 0.175 & 0.06 & 0.061 & 0.304 & 0.388 & 0.166 & 0.042 & 0.662 & 0.976 \\
\hline Dy & 0.225 & 0.822 & 0.207 & 0.232 & 0.37 & 0.706 & 0.825 & 0.686 & 1.19 & 0.413 & 0.458 & 1.8 & 2.25 & 1.09 & 0.25 & 3.63 & 5.39 \\
\hline Ho & 0.058 & 0.173 & 0.049 & 0.054 & 0.08 & 0.176 & 0.185 & 0.165 & 0.277 & 0.095 & 0.111 & 0.401 & 0.481 & 0.221 & 0.054 & 0.703 & 1.03 \\
\hline Er & 0.141 & 0.452 & 0.138 & 0.167 & 0.257 & 0.502 & 0.538 & 0.475 & 0.823 & 0.319 & 0.359 & 1.16 & 1.38 & 0.628 & 0.142 & 1.95 & 2.6 \\
\hline $\mathrm{Tm}$ & 0.024 & 0.085 & 0.024 & 0.028 & 0.042 & 0.081 & 0.079 & 0.08 & 0.151 & 0.056 & 0.061 & 0.198 & 0.256 & 0.116 & 0.015 & 0.334 & 0.405 \\
\hline $\mathrm{Yb}$ & 0.131 & 0.438 & 0.125 & 0.151 & 0.24 & 0.428 & 0.461 & 0.424 & 0.785 & 0.32 & 0.369 & 1.28 & 1.59 & 0.7 & 0.056 & 1.99 & 2.19 \\
\hline $\mathrm{Lu}$ & 0.022 & 0.064 & 0.02 & 0.023 & 0.035 & 0.06 & 0.055 & 0.055 & 0.113 & 0.045 & 0.055 & 0.177 & 0.234 & 0.104 & 0.007 & 0.272 & 0.282 \\
\hline W & 2.95 & 0.768 & 2.64 & 0.669 & 42.3 & 0.712 & 0.666 & 0.502 & 5.42 & 0.505 & 0.265 & 0.289 & 0.313 & 0.398 & 0.247 & 0.751 & 2.63 \\
\hline $\operatorname{Re}$ & $<0.002$ & $<0.002$ & $<0.002$ & $<0.002$ & $<0.002$ & $<0.002$ & $<0.002$ & $<0.002$ & $<0.002$ & $<0.002$ & $<0.002$ & $<0.002$ & 0.002 & $<0.002$ & $<0.002$ & $<0.002$ & $<0.002$ \\
\hline $\mathrm{Tl}$ & 0.01 & 0.007 & 0.008 & 0.05 & 0.186 & 0.016 & 0.1 & 0.003 & 0.11 & 0.03 & 0.044 & 0.143 & 0.107 & 0.099 & 0.01 & 0.13 & 0.409 \\
\hline $\mathrm{Pb}$ & 0.176 & 0.038 & 0.122 & 0.128 & 0.358 & 0.577 & 0.284 & 0.242 & 0.92 & 1.1 & 5.87 & 2.65 & 2.68 & 1.64 & 0.84 & 9.26 & 2.62 \\
\hline
\end{tabular}


Table 2. Cont.

\begin{tabular}{|c|c|c|c|c|c|c|c|c|c|c|c|c|c|c|c|c|c|}
\hline \multirow[b]{2}{*}{ Sample } & \multicolumn{4}{|c|}{ Calcite from Auriferous Calcite Vein } & \multicolumn{4}{|c|}{ Calcite from Red Alteration Zone } & \multicolumn{7}{|c|}{ Limestone } & \multicolumn{2}{|c|}{ Sandstone } \\
\hline & $\begin{array}{c}\text { PB- } \\
\text { PDB04-1 }\end{array}$ & $\begin{array}{c}\text { PB- } \\
\text { PDB04-2 }\end{array}$ & $\begin{array}{c}\text { PB- } \\
\text { PDB04-3 }\end{array}$ & $\begin{array}{c}\text { PB- } \\
\text { ZKB04 }\end{array}$ & $\begin{array}{c}\text { PB- } \\
\text { ZKB05-1 }\end{array}$ & $\begin{array}{c}\text { PB- } \\
\text { ZKB05-2 }\end{array}$ & $\begin{array}{c}\text { PB- } \\
\text { ZKB05-3 }\end{array}$ & $\begin{array}{c}\text { PB- } \\
\text { ZKB05-4 }\end{array}$ & $\begin{array}{c}\text { PB- } \\
\text { PDB03 }\end{array}$ & $\begin{array}{c}\text { PB- } \\
\text { PDB05-1 }\end{array}$ & $\begin{array}{c}\text { PB- } \\
\text { PDB05-2 }\end{array}$ & $\begin{array}{c}\text { PB- } \\
\text { B01-1 }\end{array}$ & $\begin{array}{c}\text { PB- } \\
\text { B01-2 }\end{array}$ & $\begin{array}{c}\text { PB- } \\
\text { ZKB02-1 }\end{array}$ & $\begin{array}{c}\text { PB- } \\
\text { ZKB02-2 }\end{array}$ & $\begin{array}{c}\text { PB- } \\
\text { PDB06 }\end{array}$ & $\begin{array}{c}\text { PB- } \\
\text { ZKB01 }\end{array}$ \\
\hline $\mathrm{Bi}$ & $<0.002$ & $<0.002$ & $<0.002$ & $<0.002$ & $<0.002$ & $<0.002$ & $<0.002$ & $<0.002$ & 0.012 & 0.06 & 0.036 & 0.051 & 0.071 & 0.018 & 0.014 & 0.207 & 0.011 \\
\hline Th & 0.007 & 0.031 & 0.013 & 0.024 & 0.023 & 0.029 & 0.043 & 0.044 & 0.249 & 0.197 & 0.191 & 1.25 & 1.23 & 0.195 & 0.115 & 5.52 & 5.58 \\
\hline $\mathrm{U}$ & 0.099 & 0.432 & 0.095 & 0.123 & 0.272 & 0.218 & 0.679 & 0.209 & 0.763 & 0.821 & 1.15 & 0.651 & 0.699 & 0.526 & 0.063 & 1.09 & 1.32 \\
\hline $\mathrm{Nb}$ & 0.009 & $<0.002$ & 0.004 & 0.005 & $<0.002$ & 0.003 & 0.005 & 0.027 & 0.268 & 0.432 & 0.405 & 1.38 & 1.4 & 0.433 & 0.343 & 5.07 & 7.83 \\
\hline $\mathrm{Ta}$ & $<0.002$ & $<0.002$ & $<0.002$ & 0.002 & 0.002 & $<0.002$ & $<0.002$ & 0.004 & 0.104 & 0.321 & 0.214 & 0.115 & 0.108 & 0.114 & 0.147 & 0.418 & 0.756 \\
\hline $\mathrm{Zr}$ & 0.104 & 0.094 & 0.125 & 0.075 & 0.057 & 0.062 & 0.035 & 0.067 & 1.35 & 1.96 & 2.47 & 17 & 18.3 & 3.46 & 0.89 & 40.4 & 68.9 \\
\hline Hf & $<0.002$ & 0.005 & $<0.002$ & $<0.002$ & 0.006 & 0.004 & 0.009 & 0.008 & 0.021 & 0.056 & 0.07 & 0.52 & 0.519 & 0.11 & 0.034 & 1.45 & 1.96 \\
\hline$\Sigma$ REE & 1.78 & 4.98 & 1.50 & 2.44 & 3.69 & 6.84 & 7.57 & 6.66 & 13.11 & 4.83 & 5.49 & 37.35 & 45.46 & 15.39 & 6.68 & 105.19 & 82.87 \\
\hline LREE & 0.98 & 2.33 & 0.76 & 1.59 & 2.35 & 4.38 & 4.75 & 4.28 & 8.81 & 3.24 & 3.74 & 30.37 & 36.86 & 11.55 & 5.81 & 92.12 & 64.54 \\
\hline HREE & 0.80 & 2.65 & 0.74 & 0.85 & 1.34 & 2.46 & 2.82 & 2.38 & 4.31 & 1.59 & 1.75 & 6.98 & 8.60 & 3.84 & 0.87 & 13.07 & 18.33 \\
\hline $\begin{array}{l}\text { LREE/ } \\
\text { HREE }\end{array}$ & 1.22 & 0.88 & 1.03 & 1.89 & 1.75 & 1.78 & 1.68 & 1.80 & 2.05 & 2.04 & 2.14 & 4.35 & 4.29 & 3.01 & 6.68 & 7.05 & 3.52 \\
\hline$\delta \mathrm{Eu}$ & 0.78 & 0.81 & 0.79 & 0.69 & 0.66 & 0.61 & 0.71 & 0.69 & 0.62 & 0.63 & 0.67 & 0.67 & 0.62 & 0.60 & 0.84 & 0.85 & 0.85 \\
\hline$\delta \mathrm{Ce}$ & 0.41 & 0.36 & 0.35 & 0.46 & 0.38 & 0.34 & 0.33 & 0.33 & 0.22 & 0.40 & 0.37 & 0.56 & 0.55 & 0.15 & 0.42 & 0.94 & 0.82 \\
\hline $\mathrm{La} / \mathrm{Ho}$ & 4.05 & 2.98 & 3.53 & 8.22 & 8.39 & 8.24 & 7.78 & 8.79 & 12.78 & 12.11 & 13.24 & 22.52 & 22.66 & 20.72 & 46.67 & 31.58 & 14.27 \\
\hline $\mathrm{Y} / \mathrm{Ho}$ & 40.2 & 43.6 & 43.7 & 49.6 & 61.0 & 56.8 & 52.3 & 57.4 & 43.7 & 63.9 & 57.8 & 34.7 & 33.9 & 39.5 & 85.6 & 28.6 & 40.5 \\
\hline $\mathrm{Tb} / \mathrm{La}$ & 0.14 & 0.22 & 0.18 & 0.08 & 0.08 & 0.07 & 0.08 & 0.06 & 0.05 & 0.05 & 0.04 & 0.03 & 0.04 & 0.04 & 0.02 & 0.03 & 0.07 \\
\hline $\mathrm{Sm} / \mathrm{Nd}$ & 0.36 & 0.34 & 0.40 & 0.27 & 0.24 & 0.24 & 0.28 & 0.22 & 0.21 & 0.21 & 0.19 & 0.20 & 0.21 & 0.20 & 0.15 & 0.20 & 0.29 \\
\hline
\end{tabular}

Notes: $\delta \mathrm{Ce}=\mathrm{Ce}_{\mathrm{N}} / \sqrt{\mathrm{La}_{\mathrm{N}} \times \operatorname{Pr}_{\mathrm{N}}}, \delta \mathrm{Eu}=\mathrm{Eu}_{\mathrm{N}} / \sqrt{\mathrm{Sm}_{\mathrm{N}} \times \mathrm{Gd}_{\mathrm{N}}}$. 
In contrast to hydrothermal calcites, the limestone have a relatively higher and wider range of the $\Sigma$ REE contents of 4.83-45.46 ppm (average of $18.33 \mathrm{ppm}$ ), and show slight REE fractionation with LREE enrichments and HREE depletions (LREE/HREE = 2.04-6.68, average of 3.51; Figure 5b). They have relatively higher $Y$ contents of $4.62-16.3$ ppm, but similar $Y /$ Ho ratios of 33.9-85.6. The negative anomalies of $\mathrm{Eu}$ and $\mathrm{Ce}$ are similar to the calcite from ores, with $\delta \mathrm{Eu}=0.60-0.84$ and $\delta \mathrm{Ce}=0.15-0.56$. The two sandstone samples have significantly higher $\Sigma$ REE contents of 82.9-105.2 ppm, and show LREE enrichment pattern (Figure $5 b)$, with nearly no Eu and Ce anomalies $(\delta \mathrm{Eu}=0.85$ and $\delta \mathrm{Ce}=0.82-0.94)$. These REE characteristics of sandstone are obviously different from the limestone, as well as the hydrothermal calcites.

\subsection{The Other Trace Elements}

The contents of other trace elements (excluding REE) in calcites, limestone and sandstone are given in Table 2, and displayed in Figure 6. The high field-strength elements (HFSEs) such as $\mathrm{Nb}$, $\mathrm{Ta}, \mathrm{Zr}$ and Hf are extremely depleted in both types of hydrothermal calcites (Figure 6a), while the limestone has only a slight depletion of $\mathrm{Nb}, \mathrm{Zr}$ and $\mathrm{Hf}$ (Figure 6b). The large ion lithophile elements (LILEs), such as $\mathrm{Rb}, \mathrm{U}$ and Th are enriched in limestone, but $\mathrm{Rb}$ is depleted in the hydrothermal calcites. Even though the contents of multi-trace elements decrease from limestone, to calcite from red alteration zone, and to calcite from auriferous calcite vein, the characteristics of trace elements are similar in all these three kinds of samples (Figure 6c). The sandstone shows obviously higher trace element contents and different characteristics compared to the limestone and hydrothermal calcites (Figure 6b).
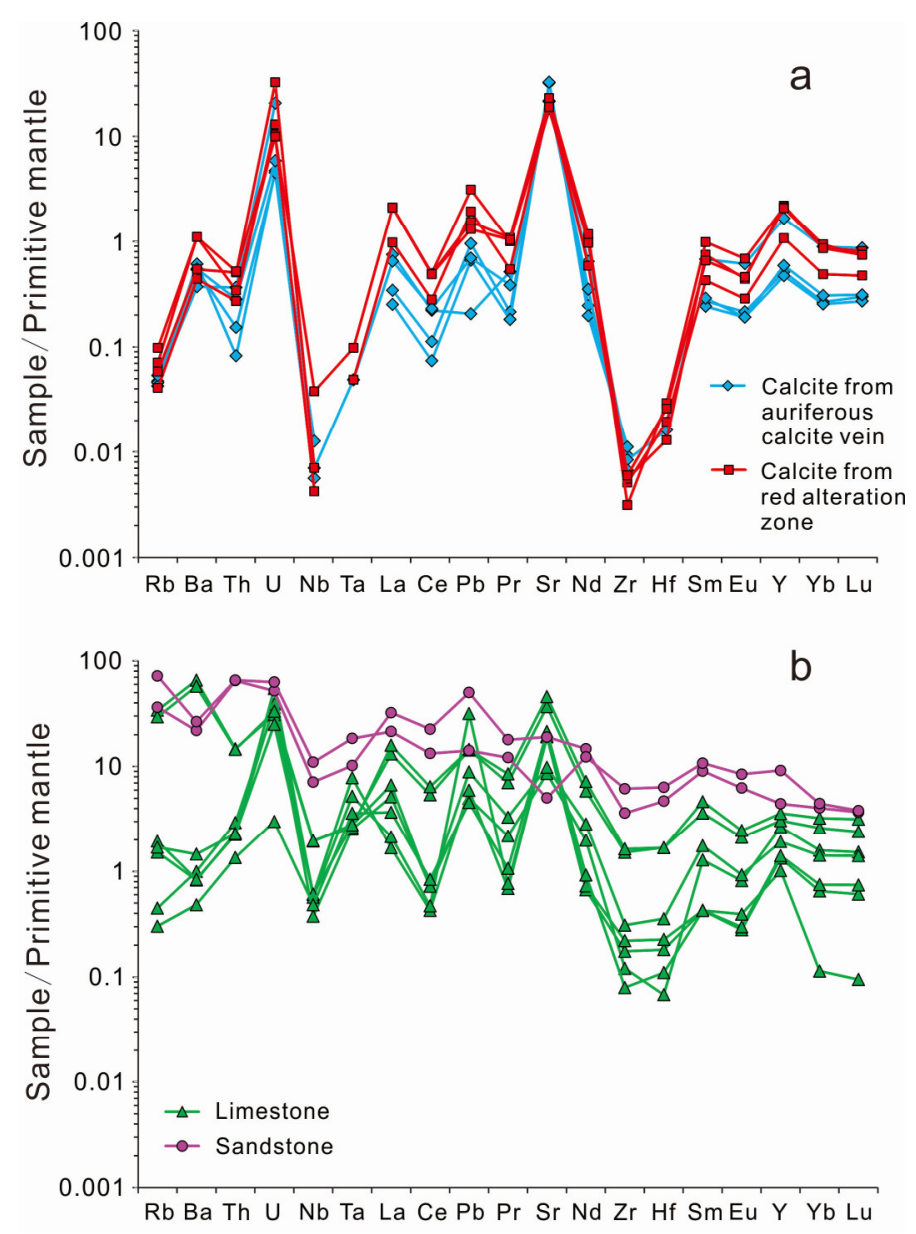

Figure 6. Cont. 


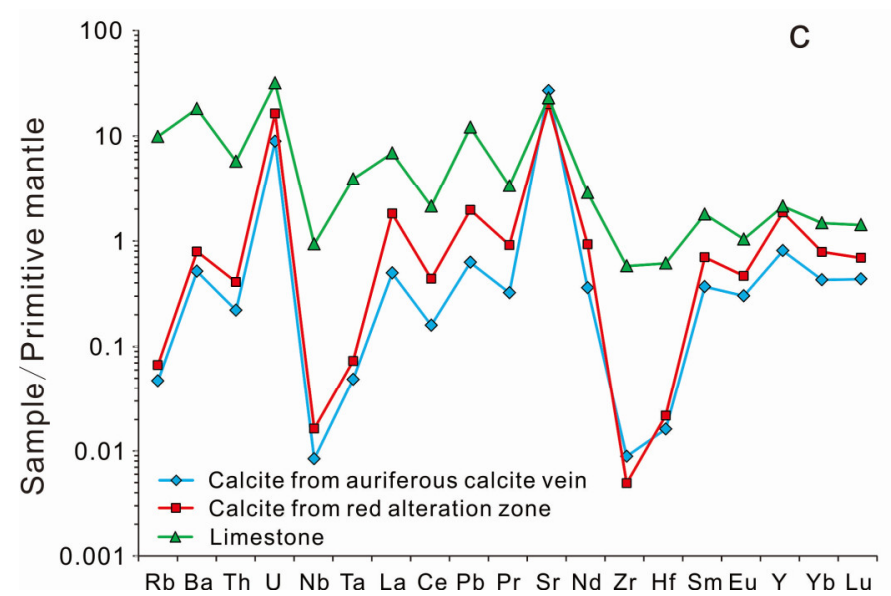

Figure 6. Trace elements distribution patterns of hydrothermal calcite and country rocks in Phapon. All samples are normalized to primitive mantle [50]. (a) Calcites from auriferous calcite vein and red alteration zone, respectively; (b) limestone and sandstone; (c) average value of two types of calcite and limestone.

\subsection{C-O Isotopic Compositions}

The carbon and oxygen isotopic composition of all the hydrothermal calcite and limestone are listed in Table 3.

Table 3. Carbon and oxygen isotope compositions of calcite and limestone from the Phapon deposit.

\begin{tabular}{cccc}
\hline Ore Type & Sample No. & $\boldsymbol{\delta}^{\mathbf{1 3}} \mathbf{C}_{\text {V-PDB }}(\%)$ & $\boldsymbol{\delta}^{\mathbf{1 8}} \mathbf{O}_{\text {V-SMOW }}(\% 0)$ \\
\hline & PB-PDB04-1 & 1.5 & 29.6 \\
Auriferous calcite vein & PB-PDB04-2 & 1.6 & 28.5 \\
& PB-PDB04-3 & 1.6 & 28.7 \\
& PB-ZKB04 & 1.7 & 23.8 \\
\hline \multirow{5}{*}{ Red alteration zone } & PB-ZKB05-1 & 1.2 & 27.5 \\
& PB-ZKB05-2 & 1.2 & 28.2 \\
& PB-ZKB05-3 & 0.7 & 28.7 \\
& PB-ZKB05-4 & 1.5 & 28.8 \\
\hline \multirow{5}{*}{ Limestone } & PB-PDB03 & 3 & 25.6 \\
& PB-PDB05-1 & 3.3 & 25.5 \\
& PB-PDB05-2 & 3.3 & 27.4 \\
& PB-B01-1 & 2.7 & 18.8 \\
& PB-B01-2 & 2.6 & 20.3 \\
& PB-ZKB02-1 & 3.6 & 26.1 \\
& PB-ZKB02-2 & 3.3 & 26.2 \\
\hline
\end{tabular}

The hydrothermal calcites have a narrow $\delta^{13} \mathrm{C}_{\mathrm{V}-\mathrm{PDB}}$ range of $0.7-1.7 \%$, with an average value of $1.4 \%$. The limestone differs from calcites by slightly increased $\delta^{13} \mathrm{C}_{\mathrm{V}-\mathrm{PDB}}(2.6-3.6 \%$, average of $3.1 \% 0)$. For two types of the calcite, the vein-type calcite $(1.5 \%$ to $1.7 \%$ ) is slightly higher than the calcite from red alteration zone $(0.7 \%$ to $1.5 \%$ ).

The hydrothermal calcites generally have a narrow $\delta^{18} \mathrm{O}_{\mathrm{V}-S M O W}$ values of $27.5-29.6 \%$, except for one lighter vein-type calcite $(23.8 \%$ ). The limestone has a wider range of oxygen isotopic compositions, and $\delta^{18} \mathrm{O}_{\mathrm{V}-\mathrm{SMOW}}$ varies between $18.8 \%$ and $27.4 \%$ (average $24.3 \%$ ). 


\section{Discussion}

\subsection{Genetic Relationships of the Two Types of Hydrothermal Calcite}

The geochemistry of REE is useful in investigating hydrothermal mineralization, as well as understanding the genesis of calcite in different geological environments [51]. Two types of hydrothermal calcite, from the calcite vein and red alteration zones respectively, have similar REE distribution patterns (Figure 5a), and previous studies also show a consistent REE characteristic of the hydrothermal calcites [11]. The calcites, moreover, show constant $\mathrm{Y} / \mathrm{Ho}$ values and are roughly horizontally distributed on the Y/Ho-La/Ho diagram (Figure 7a), indicating that both types of the calcite are probably contemporaneous crystallization and originating from the same fluid system [52,53]. The REE patterns of limestone are generally consistent with that of calcite, but the sandstones show a completely different REE pattern (Figure 5b), indicating that the calcite may have a genetic relationship with the limestone, rather than the sandstone.
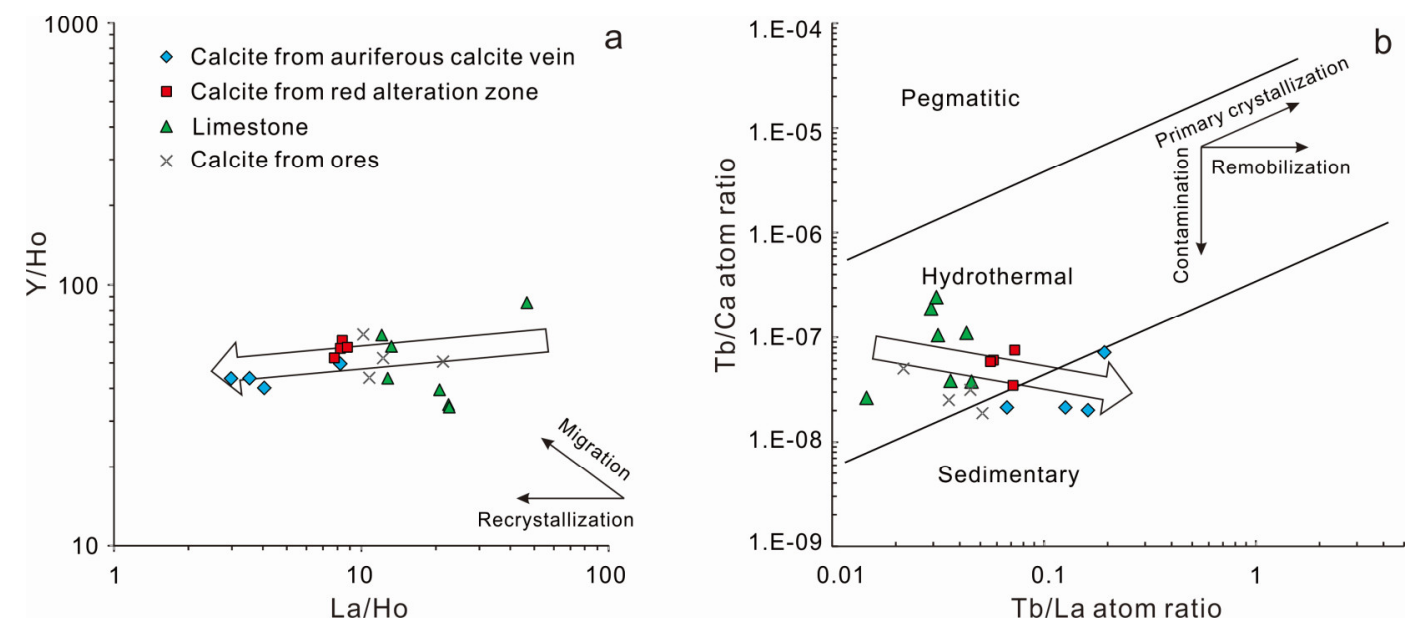

Figure 7. Plots of (a) Y/Ho versus La/Ho ratios and (b) Tb/Ca versus $\mathrm{Tb} / \mathrm{La}$ ratios for the Phapon calcite and limestone. (Base maps respectively after [52,54], the grey $\times$ symbols show hydrothermal calcite from Phapon referenced from [11]).

The two types of hydrothermal calcite, in fact, have a slight difference on LREE/HREE fractionation, except for the $\mathrm{Eu}$ and $\mathrm{Ce}$ anomalies. The calcites from red altered rock type ores have constant LREE/HREE ratios varying from 1.68 to 1.80, showing a LREE-enriched pattern. And the calcites from the auriferous calcite vein type ores have a relatively variable LREE/HREE fractionation (with minimum LREE/HREE ratio of 0.88), showing a slight LREE-depleted pattern (Figure 5a). Morgan and Wandless [55] believed that the REE pattern in hydrothermal minerals is governed by the ionic radius of the major cation and that the LREE are more easily incorporated into the calcite crystal lattice than the HREE, because the differences in ionic radii between $\mathrm{LREE}^{3+}$ and $\mathrm{Ca}^{2+}$ are smaller than these between $\mathrm{HREE}^{3+}$ and $\mathrm{Ca}^{2+}$. Therefore, the calcite should have an LREE-enriched pattern as usual, but evidently, this is not so. The LREE/HREE fractionation of hydrothermal calcite is primarily controlled by physico-chemical conditions governing the fluid during leaching of REE from source rocks, as well as fluid migration [56]. Bau and Möller [57] suggested that leaching of REE and fluid migration may occur under two different states: sorption and complexation, and specifically, complexation is more prevalent than sorption, along with an increasing $\mathrm{pH}$ and a decreasing temperature. The LREE-enriched patterns are produced in fluid under conditions favored by sorption (i.e., low $\mathrm{pH}$ and high T), alternatively, the LREE-depleted pattern should be controlled by complexation processes, due to the ligand-enriched fluid [58,59]. The complexation mechanism is considered to be responsible for the fractionation in Phapon, owing to REE complexation with ligands such as $\mathrm{CO}_{3}{ }^{2-}$ and $\mathrm{OH}^{-}$which form more stable complexes with HREE. Therefore, the early stage 
fluid should be LREE-enriched, and HREE preferentially precipitated in the late stage. Thus, the calcite from red altered rock type ores with a LREE-enriched pattern likely formed earlier than the auriferous calcite vein, which shows a slightly LREE-depleted pattern. During the fluids evolution and calcite precipitation, there are differences on not only LREE/HREE fractionation, but also $\mathrm{Tb} / \mathrm{La}$ and $\mathrm{Sm} / \mathrm{Nd}$ ratios. Constantopoulos [60] and Chesley [61] indicate that the early stage calcite has lower $\mathrm{Tb} / \mathrm{La}$ and $\mathrm{Sm} / \mathrm{Nd}$ ratios than the late stage ones. The $\mathrm{Tb} / \mathrm{La}$ ratio of vein-type calcite ranges from 0.08 to 0.22 , with an average value of 0.16 , which is higher than the calcite from the red alteration zone $(0.06-0.08)$. The vein-type calcites have also higher $\mathrm{Sm} / \mathrm{Nd}$ ratios $(0.27-0.40)$ than the calcite from red alteration zone (0.22-0.28), which also support the contention that the auriferous calcite vein may have formed later than the red alteration in Phapon.

Both types of calcite display a weak Eu negative anomaly and moderate Ce negative anomaly, suggesting low oxygen fugacities and low temperature during calcite deposition [51,62] The REE signatures of the two types of calcite are similar to the limestone, and the $\Sigma$ REE of calcite from red alteration zone contains falls in between limestone and vein-type calcite. Given that the two types of the calcites have only a little difference on REE patterns, $\mathrm{Tb} / \mathrm{La}$ and $\mathrm{Sm} / \mathrm{Nd}$ ratios and $\delta \mathrm{Eu}$ and $\delta$ Ce values, we suspect that the two types of calcite are products of different stages in the evolution of homologous fluids. The calcite from the red alteration zone formed earlier and was more affected from the limestone wallrock, whereas the auriferous calcite vein formed later and shows more characteristics from the ore fluids.

\subsection{Nature and Sources of Ore-Forming Fluids}

The $\mathrm{Y}$ and Ho generally show similar geochemical behavior and therefore the $\mathrm{Y} / \mathrm{Ho}$ ratio is widely used for tracing fluid processes as a significant parameter (e.g., $\mathrm{Xu}$ et al.; Pei et al. [63,64]). For both types of the calcite, their Y/Ho ratios vary over narrow ranges in 40.2-49.6 and 52.3-61.0, respectively, indicating a hydrothermal origin (ca. 20-110, [52]). Considering the nearly constant $\mathrm{Y} / \mathrm{Ho}$ ratios of hydrothermal calcite and the limestone wallrock, the La/Ho ratios decrease from limestone, to red alteration zone, and to auriferous calcite vein (Figure 7a), indicating the hydrothermal calcite successively formed from recrystallization of the limestone. On the other hand, the $\mathrm{Tb} / \mathrm{Ca}-\mathrm{Tb} / \mathrm{La}$ variation established by Möller et al., [54], in the form of a discriminating diagram, represents different occurrences of fluorite, calcite and other Ca-bearing minerals, according to their sedimentary, hydrothermal, and pegmatitic affinities (Figure $\mathrm{7b}$ ). $\mathrm{The} \mathrm{Tb} / \mathrm{Ca}$ and $\mathrm{Tb} / \mathrm{La}$ ratios are, respectively, criterions of the environment in which calcite forms and the crystallization proceeds degree of calcite differentiation [65]. The limestone falls across the hydrothermal and sedimentary field (Figure 7b), the calcite fall into the field of sedimentary, and no data plot in the pegmatitic field. Even though previous studies have indicated a deep-seated magmatic source based on $\mathrm{H}-\mathrm{O}$ isotopic data, the data generally fall outside the magmatic area $\left(\delta \mathrm{D}\right.$ range from $-92 \%$ to $-75 \%$ and $\delta^{18} \mathrm{O}$ range from $9 \%$ to $14 \%$ ) [11]. Thus, the magmatic fluid can be excluded. As expected, the limestone and calcite distribute along remobilization trends in Figure $7 \mathrm{~b}$, which may imply a succession from the sedimentary limestone to hydrothermal calcite.

The limestone and hydrothermal calcite respectively have narrow $\delta^{13} \mathrm{C}_{\mathrm{V}-\mathrm{PDB}}$ ranges of 2.6-3.6\% (average $3.1 \%$ ) and $0.7-1.7 \%$ (average 1.4\%o), which are higher than organic material in sedimentary rocks ( -30 to $-10 \%$; [66]), generally higher than mantle reservoir values [67], and basically within the range of marine carbonate [68] (Figure 8). The $\delta^{18} \mathrm{O}_{\mathrm{V}-\mathrm{SMOW}}$ of limestone and hydrothermal calcite ranges from 18.8 to $29.6 \%$, which are significantly higher than igneous carbonate and mantle xenoliths, and can be preclude from the process of crystallization differentiation.

The two types of hydrothermal calcite and limestone have similar trace elements (exclude REE) characteristics (Figure 6), and the HFSEs such as $\mathrm{Nb}, \mathrm{Ta}, \mathrm{Zr}$ and Hf are extremely depleted, which may indicate the mixing of crustal-source fluid. Thus, the ore-forming fluids should be a single fluid that was not associated with magmatic or mantle fluid. As stated above, the contents of multi-trace elements decrease from limestone, to calcite from red alteration zone, and to calcite from auriferous 
calcite vein (Figure 6c), which is the same as those of the $\Sigma$ REE signatures. The later vein-type calcite contains lower trace element content than earlier calcite from the red alteration zone, which could be explained as the lower total trace element concentrations in the fluids in late stage, which means the ore-forming fluids have been diluted by meteoric waters during late stage [69]. Combined with the $\mathrm{Y} / \mathrm{Ho}-\mathrm{La} / \mathrm{Ho}$ and $\mathrm{Tb} / \mathrm{Ca}-\mathrm{Tb} / \mathrm{La}$ diagram (Figure 7) that argue the hydrothermal calcite may formed from remobilization and recrystallization of the limestone, and the similar REE patterns between hydrothermal calcite and limestone, the ore-forming fluids are suspected to be primarily associated with dehydration and decarbonization of the Lower Permian limestone and Middle-Upper Triassic sandstones during a regional dynamic metamorphism, shown as a thrust nappe structure in the shallow ground.

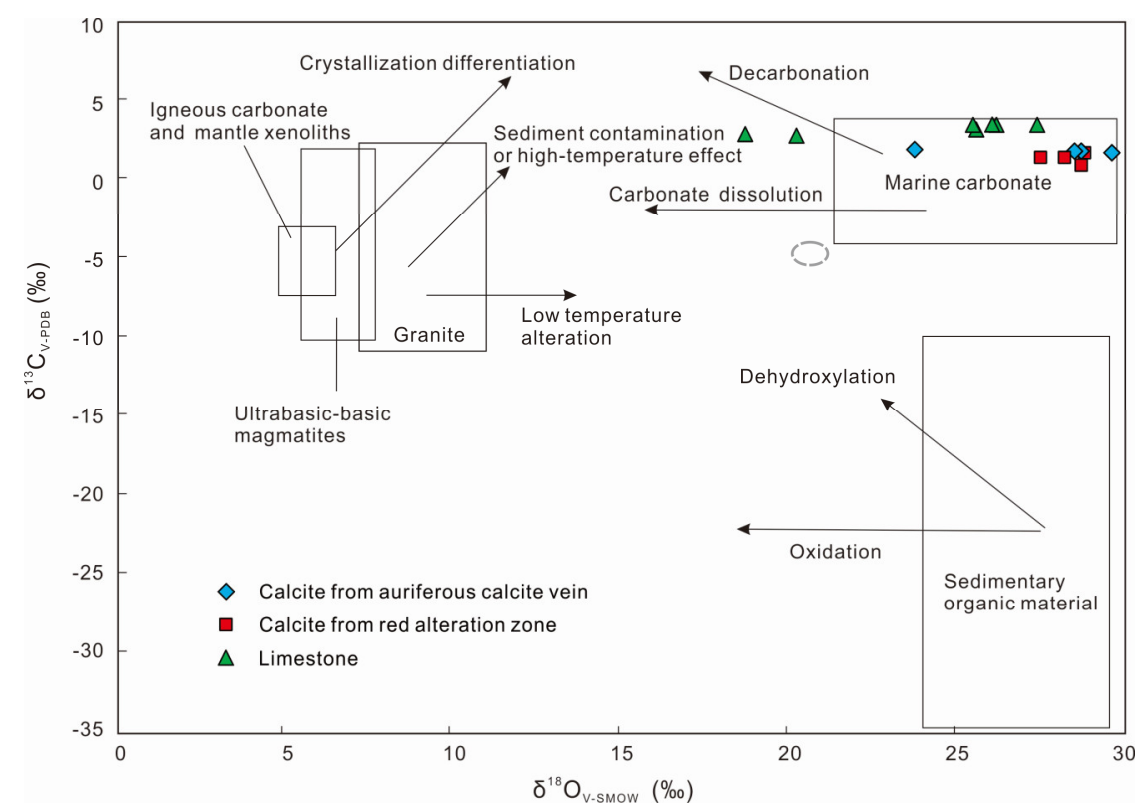

Figure 8. The $\delta^{13} \mathrm{C}_{\mathrm{V}-\mathrm{PDB}}$ and $\delta^{18} \mathrm{O}_{\mathrm{V}-\mathrm{SMOW}}$ values of calcite from the Phapon gold deposit. The area in grey dashed line shows $\delta^{13} \mathrm{C}_{\mathrm{V}-\mathrm{PDB}}-\delta^{18} \mathrm{O}_{\mathrm{V}-\mathrm{SMOW}}$ values of hydrothermal calcite from Phapon [15]. References for the fields of major carbon reservoirs and other deposits are from [68].

\subsection{Implications for Ore-Forming Processes}

During the migration of hydrothermal solutions up in the fractured zone, gold is normally dissolved and transported in the form of gold chloride complexes $\left(\mathrm{AuCl}^{2-}\right)$ and gold bisulfide complexes $\left[\mathrm{Au}(\mathrm{HS})_{2}{ }^{-}\right][70,71]$. Gold chloride complexes $\left(\mathrm{AuCl}^{2-}\right)$ normally exist in near-neutral to weakly alkaline ore fluids at $>400{ }^{\circ} \mathrm{C}$ [72], whereas the $\mathrm{Au}(\mathrm{HS})_{2}{ }^{-}$are important in near-neutral to weakly acidic ore fluids with temperatures of $<400{ }^{\circ} \mathrm{C}$ [73]. The calcite-quartz mineral assemblages in the Phapon gold deposit indicate that the $\mathrm{pH}$ values of ore fluids were near-neutral to weakly acidic. The ore-forming temperature should be lower than $400{ }^{\circ} \mathrm{C}$, because of the negative anomaly of Eu and Ce of hydrothermal calcite, as well as fluid inclusion microthermometry [10]. Thus gold bisulfide complexes, mainly $\mathrm{Au}(\mathrm{HS})_{2}{ }^{-}$, were the gold-transporting species (e.g., Pokrovski et al. [74]), and gold-deposition may be the result of the breakdown of $\mathrm{Au}(\mathrm{HS})_{2}{ }^{-}[75,76]$.

Hydrothermal alteration, particularly the siderite alteration, is widely developed in the Phapon gold deposit (Figure 3b). Interaction between Fe-bearing orefluids and carbonate minerals in wall-rocks, to form siderite is in terms of the following equations [77]:

$$
\begin{gathered}
\mathrm{Fe}^{2+}+\left(\mathrm{HCO}_{3}\right)^{-}=\mathrm{FeCO}_{3}+\mathrm{H}^{+} \\
\mathrm{H}_{2} \mathrm{~S}(\mathrm{~g})=\mathrm{H}^{+}+\mathrm{HS}^{-}
\end{gathered}
$$




$$
4 \mathrm{Au}(\mathrm{HS})_{2}{ }^{-}+2 \mathrm{H}_{2} \mathrm{O}+8 \mathrm{H}^{+} \text {(aq.) }=4 \mathrm{Au}^{0} \text { (s) }+8 \mathrm{H}_{2} \mathrm{~S} \text { (aq.) }+\mathrm{O}_{2}
$$

The processes would decrease the solubility of $\mathrm{Au}(\mathrm{HS})_{2}{ }^{-}$and lead to gold deposition (e.g., Guo et al.; Yang et al. [78-80]), indicating that fluid-wallrock interaction played a major role in gold mineralization.

As discussed above, the potential fluid reservoirs could be associated with dehydration and decarbonization of Lower Permian-Middle Triassic sedimentary formations; the mineralization events cannot be earlier than Early to Middle Triassic. The Loei belt mineralization systems are mainly linked to one of the two subduction-related systems [36]: (1) Late Permian-Middle Triassic continental arcs, and (2) Late Triassic-Jurassic post-collisional magmatism. As there was no geochronological data reported in the Phapon deposit, the gold deposition in the Phapon deposit occurred, more likely, during the regional dynamic metamorphism, driven by Late Triassic-Jurassic post-collisional magmatism. Combined with the geological and geochemical studies, the process of geotectonic evolution and gold mineralization in Phapon is presumed as follows:

The basin of Luang Prabang in Laos subsided deeper in Early Permian, and sedimented thickly-bedded carbonate rocks. The Nan-Sra Kaeo back arc basins may have begun to form close to the Late Permian to Early Triassic, through east-vergent subduction of Sibumasu underneath the Indochina terrane, forming Nan-Uttaradit Suture [34], which created the Loei continental arc magmatism and its associated porphyry-related skarn and epithermal deposits (Figure 1), as well as continental clastic rocks and NE-trending brittle-ductile shear zones in the Phapon area (Figure 2). Continuous subduction along the Loei fold belts finally brought about the Indochina-Sibumasu collision during the Triassic-Jurassic, which represent a significant metallogenic epoch for many orogenic gold deposits along the Sukhothai- and East Malaya-terrane/fold belts [36] (Figure 1).

In Phapon area, the Late Triassic-Jurassic collision and post-collision caused the southeastern Permian limestone to be thrusted northward and superimposed on the Triassic sandstone. Strong tectonic activities led to ductile-brittle shearing along the lithological difference surface (Figure 3a,b), followed by dynamic metamorphism, and dehydration and decarbonation of Lower Permian limestone which created metamorphic fluids. At the same time, the NE-trending faults, formed during Late Permian-Early Triassic, reactivated with compression-torsion activities, forming deep faults and regional magmatism (locally diabase and dioritic porphyrite). A series of NNW-trending extension secondary faults, formed simultaneously, are identified as fluid channels and important ore-bearing spaces. The metamorphic fluid began to enter the limestone along the extension secondary faults. Even though the magmatic fluids may not have played a role in the gold mineralization, the regional magmatic events were likely to provide a heat source for driving fluid circulation. The fluids reacted with the surrounding sedimentary formation with relatively high gold concentration $\left(4.56 \times 10^{-9}\right.$, , [13]), and mixed with near-surface meteoric waters. Gold deposited primary in the red alteration zones, as a result of the interaction between Fe-bearing orefluids and carbonate minerals in wall-rocks, and subsequently deposited in massive calcite veins.

As mentioned above, the gold mineralization in the Phapon gold deposit is completely different from the porphyry-related skarn and epithermal systems. It is also different from the sediment-hosted carlin-type gold that has submicron gold in pyrite [81], and the orogenic gold deposits in the East Malaya terrane that output ores with quartz-sulfide assemblage [82]. However, a number of features in Phapon are similar to orogenic gold systems: (1) strong structural control on the deposits by NNW-trending brittle faults (e.g., Deng et al. [83-85]); (2) lack of metal zonation; (3) occurrence of free gold in calcite; (4) extremely high Au/Ag ratio (much higher than 10, with average silver grade of $0.05 \mathrm{~g} / \mathrm{t}$ ) of the ores [14]; and (5) relative low fluid salinity (average 7.64\%, [10]). Combined with the relatively shallower metallogenic depth (ca. $0.48-1.77 \mathrm{~km}$, [8]), the appearance of low-temperature minerals such as realgar and orpiment, and the predominantly brittle deformation textures in ores, the Phapon gold deposit is compatible with an epizonal orogenic deposit (e.g., Gebre-Mariam et al.; Groves et al.; Yang et al.; [86-89]). 


\section{Conclusions}

(1) The two types of hydrothermal calcite, respectively from auriferous calcite veins and red alteration zone, show a nearly consistent REE characteristic, and could be formed from remobilization and recrystallization of the ore-hosted limestone.

(2) The two types of calcite are products of homologous fluids. The calcite from red alteration zone formed earlier and was more affected by the limestone wallrock, whereas the auriferous calcite vein formed later and showed more characteristics from the ore fluids.

(3) The ore-forming fluids are suspected to be primarily associated with dehydration and decarbonization of the Lower Permian limestone and Middle-Upper Triassic sandstones during a regional dynamic metamorphism, and were probably mixed by meteoric waters during the formation of the massive calcite veins.

(4) Gold mineralization in Phapon probably occurred during the Late Triassic-Jurassic regional dynamic metamorphism driven by Indochina-Sibumasu post-collisional magmatism. A number of features in Phapon are compatible with an epizonal orogenic deposit, but it is still a unique calcite vein type gold deposit in the Luang Prabang-Loei metallogenic belt.

Author Contributions: Conceptualization, L.G. and L.H.; Data curation, L.G.; Formal analysis, L.G.; Funding acquisition, S.L.; Investigation, L.G. and L.H.; Project administration, S.L.; Writing-original draft, L.G.; Writing-review and editing, L.G., L.H. and F.N.

Funding: This research was funded by the China Geological Survey Project, grant No. 121201010000150013.

Acknowledgments: We thank the geologists from the Tianjin Huakan Mining Investment, Co, Ltd with their assistance in the field work for the Phapon gold deposit.

Conflicts of Interest: The authors declare no conflict of interest.

\section{References}

1. Goldfarb, R.J.; Taylor, R.D.; Collins, G.S.; Goryachev, N.A.; Orlandini, O.F. Phanerozoic continental growth and gold metallogeny of Asia. Gondwana Res. 2014, 25, 48-102. [CrossRef]

2. Deng, J.; Wang, Q.F. Gold mineralization in China: Metallogenic provinces, deposit types and tectonic framework. Gondwana Res. 2016, 36, 219-274. [CrossRef]

3. Zhao, Y.P.; Kang, T.S.; Ning, G.C.; Ge, H.; Pan, H. Geochemical characteristics of the volcanic intrusive complex in the Pangkuam copper-gold deposit of Laos and its geological significance. Acta Petrol. Mineral. 2017, 36, 281-294. (In Chinese with English Abstract).

4. Shi, M.F.; Lin, F.C.; Fan, W.Y.; Deng, Q.; Cong, F.; Tran, M.D.; Zhu, H.P.; Wang, H. Zircon U-Pb ages and geochemistry of granitoids in the Truong Son terrane, Vietnam: Tectonic and metallogenic implications. J. Asian Earth Sci. 2015, 101, 101-120. [CrossRef]

5. Lin, F.C.; Shi, M.F.; Li, X.Z. Geological Background and Metallogenic Regularities of the Sanjiang-Mekong Metallogenic Belt; Internal materials of Chengdu Center, China Geological Survey: Chengdu, China, 2010; p. 437. (In Chinese)

6. Shao, C.L. The geological characteristics and prospecting criteria of the Phabon gold deposit, Laos. Geol. Surv. Res. 2011, 34, 203-209. (In Chinese with English Abstract).

7. Liu, X.C.; Zhang, R.H.; Che, L.K. Geological characteristics of B. Phatem primary gold deposit, Laos and the ore-searching directions. Contrib. Geol. Miner. Resour. Res. 2010, 25, 171-176. (In Chinese with English Abstract).

8. Dai, F.Y.; Niu, Y.J. Characters of mineralogy and genesis of Phabon gold deposit in Luang Prabang Province, Laos. Miner. Explor. 2014, 5, 511-518. (In Chinese with English Abstract).

9. Shi, L.H.; Xue, L.H.; Sun, H.Y. Characteristic of wall rock alteration and its relation with gold mineralization of the Phapon gold deposit in Laos. Geol. Surv. Res. 2016, 39, 184-190. (In Chinese with English Abstract).

10. Lu, F.F.; Yang, H.L.; Tong, W.H.; Zhao, M.S. Inclusion characteristics of Phabon gold deposit, Laos. Henan Sci. 2015, 33, 1985-1989. (In Chinese with English Abstract). 
11. Niu, Y.J.; Liu, W.; Gao, Y.L.; Liu, Z.Y.; Yang, H.L.; Yu, W.X. Geochemical characteristics of stable isotopes and REE at the PHAPUN gold deposit in Laos. Geol. Surv. Res. 2015, 3, 277-283. (In Chinese with English Abstract).

12. Li, H.K.; Zhang, X.J.; Wang, J. Genesis of Phapon Au deposit in Luangprabang, Laos. Yunnan Geol. 2011, 30, 280-284. (In Chinese with English Abstract).

13. Yang, C.Z.; Shen, L.X.; Zhou, L.; Feng, J.Z.; Liu, X.W. Characteristics of geology and structural geochemistry and metallogenic mechanism of Phapon gold deposit in Laos. Miner. Resour. Geol. 2017, 31, 11-22. (In Chinese with English Abstract).

14. Xue, L.H.; Shi, L.H. Mineralization and metallogenic evolution of the Phapon gold deposit, Laos. Geol. Surv. Res. 2016, 39, 191-203. (In Chinese with English Abstract).

15. Niu, Y.J.; Sun, H.Y.; Wang, J.S.; Chen, J.Y.; Liu, Z.Y.; Wang, K. Study on feature of ore-forming fluid and ore genesis of Phapon gold deposit, Luangprobang, Laos. Contrib. Geol. Miner. Resour. Res. 2017, 32, 317-323. (In Chinese with English Abstract).

16. Wang, H.; Lin, F.C.; Li, X.Z.; Shi, M.F. The division of tectonic units and tectonic evolution in Laos and its adjacent regions. Geol. China 2015, 42, 71-83. (In Chinese with English Abstract).

17. Hinton, R.W.; Upton, B.J.G. The chemistry of zircon: Variations within and between large crystals from syenite and alkali basalt xenoliths. Geochim. Cosmochim. Acta 1991, 55, 3287-3302. [CrossRef]

18. Orman, J.A.V.; Grove, T.L.; Shimizu, N.; Graham, D.L. Rare earth element diffusion in diopside: Influence of temperature, pressure and ionic radius and an elastic model for diffusion in silicates. Contrib. Mineral. Petrol. 2001, 141, 687-703. [CrossRef]

19. Brugger, J.; Etschmann, B.; Pownceby, M.; Liu, W.; Grundler, P.; Brewe, D. Oxidation state of europium in scheelite: Tracking fluidrock interaction in gold deposits. Chem. Geol. 2008, 257, 26-33. [CrossRef]

20. Peng, J.T.; Zhang, D.L.; Hu, R.Z.; Wu, M.J.; Liu, X.M.; Qi, L.; Yu, Y.G. Inhomogeneous distribution of rare earth elements (REEs) in scheelite from the Zhazixi W-Sb deposit, western Hunan and its geological implications. Geol. Rev. 2010, 56, 810-820. (In Chinese with English Abstract).

21. Schönenberger, J.; Köhler, J.; Markl, G. REE systematics of fluorides, calcite and siderite in peralkaline plutonic rocks from the Gardar Province, South Greenland. Chem. Geol. 2008, 247, 16-35. [CrossRef]

22. Dostal, J.; Kontak, D.; Chatterjee, A.K. Trace element geochemistry of scheelite and rutile from metaturbidite-hosted quartz vein gold deposits, Meguma Terrane, Nova Scotia, Canada: Genetic implications. Mineral. Petrol. 2009, 97, 95-109. [CrossRef]

23. Brugger, J.; Lahaye, Y.; Costa, S.; Lambert, D.; Bateman, R. Inhomogeneous distribution of REE in scheelite and dynamics of Archaean hydrothermal systems (Mt. Charlotte and Drysdale gold deposits, Western Australia). Contrib. Mineral. Petrol. 2000, 139, 251-264. [CrossRef]

24. Bau, M.; Romer, R.L.; Lüders, V.; Dulski, P. Tracing element sources of hydrothermal mineral deposits: REE and $\mathrm{Y}$ distribution and $\mathrm{Sr}-\mathrm{Nd}-\mathrm{Pb}$ isotopes in fluorite from MVT deposits in the Pennine orefield, England. Miner. Depos. 2003, 38, 992-1008. [CrossRef]

25. Zhang, D.L.; Peng, J.T.; Fu, Y.Z.; Peng, G.X. Rare-earth element geochemistry in Ca-bearing minerals from the Xianghuapu tungsten deposit, Hunan Province, China. Acta Petrol. Sin. 2012, 28, 65-74. (In Chinese with English Abstract).

26. Wang, J.S.; Wen, H.J.; Fan, H.F.; Zhu, J.J.; Zhang, J.R. Sm-Nd geochronology, REE geochemistry and C and O isotope characteristics of calcites and stibnites from the Banian antimony deposit, Guizhou Province, China. Geochem. J. 2013, 46, 393-407. (In Chinese with English Abstract). [CrossRef]

27. Wu, Y.; Zhang, C.Q.; Tian, G. REE geochemistry of fluorite from Paoma lead-zinc deposit in Sichuan Province, China and its geological implications. Acta Mieral. Sin. 2013, 33, 295-301. (In Chinese with English Abstract).

28. Cao, H.W.; Zhang, W.; Pei, Q.M.; Zhang, S.T.; Zheng, L. Trace element geochemistry of fluorite and calcite from the Xiaolonghe Tin deposits and Lailishan Tin deposits in Western Yunnan, China. Bull. Mineral. Petrol. Geochem. 2016, 35, 925-935. (In Chinese with English Abstract).

29. Deng, J.; Wang, Q.F.; Li, G.J.; Li, C.S.; Wang, C.M. Tethys tectonic evolution and its bearing on the distribution of important mineral deposits in the Sanjiang region, SW China. Gondwana Res. 2014, 26, 419-437. [CrossRef]

30. Deng, J.; Wang, Q.F.; Li, G.J.; Santosh, M. Cenozoic tectono-magmatic and metallogenic processes in the Sanjiang region, southwestern China. Earth-Sci. Rev. 2014, 138, 268-299. [CrossRef] 
31. Yang, L.Q.; He, W.Y.; Gao, X.; Xie, S.X.; Yang, Z. Mesozoic multiple magmatism and porphyry-skarn Cu-polymetallic systems of the Yidun Terrane, Eastern Tethys: Implications for subduction- and transtension-related metallogeny. Gondwana Res. 2018, 62, 144-162. [CrossRef]

32. Phajuy, B.; Panjasawatwong, Y.; Osataporn, P. Preliminary geochemical study of volcanic rocks in the Pang Mayao area, Phrao, Chiang Mai, Northern Thailand: tectonic setting of formation. J. Asian Earth Sci. 2005, 24, 765-776. [CrossRef]

33. Zaw, K.; Meffre, S. Metallogenic Relations and Depositscale Studies, Final Report: Geochronology, Metallogenesis and Deposit Styles of Loei Fold Belt in Thailand and Laos PDR; ARC Linkage Project, CODES with Industry Partners; University of Tasmania: Hobart, Australia, 2007.

34. Salam, A. A Geological, Geochemical and Metallogenic Study of the Chatree Epithermal Deposit, Petchabun Province, Central Thailand. Ph.D. Thesis, ARC Centre of Excellence in Ore Deposits (CODES), University of Tasmania, Hobart, Australia, 2013; p. 250.

35. Salam, A.; Zaw, K.; Meffre, S.; Mcphie, J.; Lai, C.K. Geochemistry and geochronology of epithermal $\mathrm{Au}$-hosted Chatree volcanic sequence: Implication for tectonic setting of the Loei Fold Belt in central Thailand. Gondwana Res. 2014, 26, 198-217. [CrossRef]

36. Qian, X.; Feng, Q.L.; Wang, Y.J.; Chonglakmani, C.; Monjai, D. Geochronological and geochemical constraints on the mafic rocks along the Luang Prabang zone: Carboniferous back-arc setting in northwest Laos. Lithos 2016, 245, 60-75. [CrossRef]

37. Qian, X.; Feng, Q.L.; Yang, W.Q.; Wang, Y.J.; Chonglakmani, C.; Monjai, D. Arc-like volcanic rocks in NW Laos: Geochronological and geochemical constraints and their tectonic implications. J. Asian Earth Sci. 2015, 98, 342-357. [CrossRef]

38. Rossignol, C.; Bourquin, S.; Poujol, M.; Hallot, E.; Dabard, M.P.; Nalpas, T. The volcaniclastic series from the Luang Prabang Basin, Laos: A witness of a triassic magmatic arc? J. Asian Earth Sci. 2016, 120, 159-183. [CrossRef]

39. Qian, X.; Feng, Q.L.; Wang, Y.J.; Yang, W.Q.; Chonglakmani, C.; Monjai, D. Petrochemistry and tectonic setting of the Middle Triassic arc-like volcanic rocks in the Sayabouli Area, NW Laos. J. Earth Sci. 2016, 27, 365-377. [CrossRef]

40. Blanchard, S.; Rossignol, C.; Bourquin, S.; Dabard, M.P.; Hallot, E.; Nalpas, T. Late Triassic volcanic activity in South-East Asia: New stratigraphical, geochronological and paleontological evidence from the Luang Prabang Basin (Laos). J. Asian Earth Sci. 2013, 70-71, 8-26. [CrossRef]

41. Kamvong, T.; Zaw, K.; Meffre, S.; Maas, R.; Stein, H.; Lai, C.K. Adakites in the Truong Son and Loei fold belts, Thailand and Laos: Genesis and implications for geodynamics and metallogeny. Gondwana Res. 2014, 26, 165-184. [CrossRef]

42. Kamvong, T.; Zaw, K. The origin and evolution of skarn-forming fluids from the Phu Lon deposit, northern Loei Fold Belt, Thailand: Evidence from fluid inclusion and sulfur isotope studies. J. Asian Earth Sci. 2009, 34, 624-633. [CrossRef]

43. Zaw, K.; Kamvong, T.; Khositanont, S.; Mernagh, T.P. Oxidized vs. reduced Cu-Au skarn formation and implication for exploration, Loei and Truong Son fold belts, SE Asia. In Proceedings of the International Conference on Geology, Geotechnology and Mineral Resources of Indochina (GEOINDO 2011), Khon Kean, Thailand, 1-3 December 2011; pp. 97-100.

44. Zaw, K.; Meffre, S.; Lai, C.K.; Burrett, C.; Santosh, M.; Graham, I.; Manaka, T.; Salam, A.; Kamvong, T.; Cromie, P. Tectonics and metallogeny of mainland Southeast Asia-A review and contribution. Gondwana Res. 2014, 26, 5-30. [CrossRef]

45. Tangwattananukul, L.; Ishiyama, D.; Matsubaya, O.; Mizuta, T.; Charusiri, P. Gold mineralization of Q prospect at Chatree deposit, central Thailand. NMCC Annu. Rep. 2009, 16, 70-75.

46. Qiu, K.F.; Taylor, R.D.; Song, Y.H.; Yu, H.C.; Song, K.R.; Li, N. Geologic and geochemical insights into the formation of the Taiyangshan porphyry copper-molybdenum deposit, Western Qinling Orogenic Belt, China. Gondwana Res. 2016, 35, 40-58. [CrossRef]

47. Qiu, K.F.; Marsh, E.; Yu, H.C.; Pfaff, K.; Gulbransen, C.; Gou, Z.Y.; Li, N. Fluid and metal sources of the Wenquan porphyry molybdenum deposit, Western Qinling, NW China. Ore Geol. Rev. 2017, 86, 459-473. [CrossRef] 
48. Liu, Y.S.; Hu, Z.C.; Gao, S.; Günthe, D.; Xu, J.; Gao, C.G.; Chen, H.H. In situ analysis of major and trace elements of anhydrous minerals by LA-ICP-MS without applying an internal standard. Chem. Geol. 2008, 257, 34-43. [CrossRef]

49. Liu, H.B.; Jin, G.S.; Li, J.J.; Han, J.; Zhang, J.F.; Zhang, J.; Zhong, F.W.; Guo, D.Q. Determination of stable isotope composition in uranium geological samples. World Nucl. Geosci. 2013, 3, 174-179. (In Chinese with English Abstract).

50. Sun, S.S.; McDonough, W.F. Chemical and isotopic systematics of oceanic basalts: Implications for mantle composition and processes. Geol. Soc. Lond. Spec. Publ. 1989, 42, 313-345. [CrossRef]

51. Schwinn, G.; Markl, G. REE systematics in hydrothermal fluorite. Chem. Geol. 2005, 216, 225-248. [CrossRef]

52. Bau, M.; Dulski, P. Comparative study of yttrium and rare-earth element behavior in fluorine-rich hydrothermal fluids. Contrib. Mineral. Petrol. 1995, 119, 213-223. [CrossRef]

53. Shuang, Y.; Bi, X.W.; Hu, R.Z.; Peng, J.T.; Li, Z.L.; Li, X.M.; Yuan, S.D.; Qi, Y.Q. REE geochemistry of hydrothermal calcite from tin-polymetallic deposit and its indication of source of hydrothermal ore-forming fluid. J. Mineral. Petrol. 2006, 26, 57-65. (In Chinese with English Abstract).

54. Möller, P.; Parekh, P.P.; Schneider, H.J. The application of Tb/Ca-Tb/La abundance ratios to problems of fluorspar genesis. Miner. Depos. 1976, 11, 111-116. [CrossRef]

55. Morgan, J.W.; Wandless, G.A. Rare earth elements in some hydrothermal minerals: Evidence for crystallographic control. Geochim. Cosmochim. Acta 1980, 44, 973-980. [CrossRef]

56. Michard, A. Rare earth element systematics in hydrothermal fluids. Geochim. Cosmochim. Acta 1989, 53, 745-750. [CrossRef]

57. Bau, M.; Möller, P. Rare earth element fractionation in metamorphogenic hydrothermal calcite, magnesite and siderite. Mineral. Petrol. 1992, 45, 231-246. [CrossRef]

58. Bau, M. Rare-earth element mobility during hydrothermal and metamorphic fluid-rock interaction and the significance of the oxidation state of europium. Chem. Geol. 1991, 93, 219-230. [CrossRef]

59. Subías, I.; Fernández-Nieto, C. Hydrothermal events in the Valle de Tena (Spanish Western Pyrenees) as evidenced by fluid inclusions and trace-element distribution from fluorite deposits. Chem. Geol. 1995, 124, 267-282. [CrossRef]

60. Constantopoulos, J. Fluid inclusions and rare-earth element geochemistry of fluorite from south-central Idaho. Econ. Geol. 1988, 88, 626. [CrossRef]

61. Chesley, J.T.; Halliday, A.N.; Scrivener, R.C. Samarium-Neodymium Direct of Fluorite. Science 1991, 252, 949-951. [CrossRef] [PubMed]

62. Ghaderi, M.; Palin, J.M.; Campbell, I.H.; Sylvester, P.J. Rare earth element systematics in scheelite from hydrothermal gold deposits in the Kalgoorlie-Norseman region, Western Australia. Econ. Geol. 1999, 94, 423-437. [CrossRef]

63. Xu, C.; Taylor, R.N.; Li, W.; Kynicky, J.; Chakhmouradian, A.R.; Song, W. Comparison of fluorite geochemistry from REE deposits in the Panxi region and Bayan Obo, China. J. Asian Earth Sci. 2012, 57, 76-89. [CrossRef]

64. Pei, Q.M.; Zhang, S.T.; Santosh, M.; Cao, H.W.; Zhang, W.; Hu, X.K.; Wang, L. Geochronology, geochemistry, fluid inclusion and $\mathrm{C}, \mathrm{O}$ and $\mathrm{Hf}$ isotope compositions of the Shuitou fluorite deposit, Inner Mongolia, China. Ore Geol. Rev. 2017, 83, 174-190. [CrossRef]

65. Möller, P.; Morteani, G. On the chemical fractionation of REE during the formation of Ca-minerals and its application to problems of the genesis of ore deposits. In The Significance of Trace Elements in Solving Petrogenetic Problems; Augustithis, S., Ed.; Theophrastus Publications: Athens, Greece, 1983; pp. 747-791.

66. Faure, G. Principles of Isotope Geology, 2nd ed.; Wiley: New York, NY, USA, 1986; pp. 1-589.

67. Ohmoto, H. Systematics of sulfur and carbon isotopes in hydrothermal ore deposits. Econ. Geol. 1972, 67, 551-578. [CrossRef]

68. Liu, J.M.; Liu, J.J.; Zheng, M.H.; Gu, X.X. Stable isotope compositions of micro-disseminated gold and genetic discussion. Geochimica 1988, 27, 585-591.

69. Assadzadeh, G.E.; Samson, I.M.; Gagnon, J.E. The trace element chemistry and cathodoluminescence characteristics of fluorite in the Mount Pleasant Sn-W-Mo deposits: Insights into fluid character and implications for exploration. J. Geochem. Explor. 2017, 172, 1-19. [CrossRef]

70. Seward, T.M. Thio complexes of gold and the transport of gold in hydrothermal ore solutions. Geochim. Cosmochim. Acta 1973, 37, 379-399. [CrossRef] 
71. Hayashi, K.I.; Ohmoto, H. Solubility of gold in NaCl- and H2S-bearing aqueous solutions at $250-350{ }^{\circ} \mathrm{C}$. Geochim. Cosmochim. Acta 1991, 55, 2111-2126. [CrossRef]

72. Gammons, C.H.; Williams-Jones, A.E.; Yu, Y. New data on the stability of gold (I) chloride complexes at $300{ }^{\circ}$ C. Mineral. Mag. A 1994, 58, 309-310. [CrossRef]

73. Benning, L.G.; Seward, T.M. Hydrosulphide complexing of gold (I) in hydrothermal solutions from 150 to $500{ }^{\circ} \mathrm{C}$ and 500 to 1500 bars. Geochim. Cosmochim. Acta 1996, 60, 1849-1871. [CrossRef]

74. Pokrovski, G.S.; Tagirov, B.R.; Schott, J.; Hazemann, J.L.; Proux, O. A new view on gold speciation in sulfur-bearing hydrothermal fluids from in situ X-ray absorption spectroscopy and quantum-chemical modeling. Geochim. Cosmochim. Acta 2009, 73, 5406-5427. [CrossRef]

75. Cox, S.F.; Sun, S.S.; Etheridge, M.A.; Wall, V.J.; Potter, T.F. Structural and geochemical controls on the development of turbidite-hosted gold quartz vein deposits, Wattle Gully mine, central Victoria, Australia. Econ. Geol. 1995, 90, 1722-1746. [CrossRef]

76. Mikucki, E.J. Hydrothermal transport and depositional processes in Archean lode-gold systems: A review. Ore Geol. Rev. 1998, 13, 307-321. [CrossRef]

77. Williams-Jones, A.E.; Bowell, R.J.; Migdisov, A.A. Gold in solution. Elements 2009, 5, 281-287. [CrossRef]

78. Guo, L.N.; Zhang, C.; Song, Y.Z.; Chen, B.H.; Zhou, Z.; Zhang, B.L.; Xu, X.L.; Wang, Y.W. Hydrogen and oxygen isotopes geochemistry of the Wang'ershan gold deposit, Jiaodong. Acta Petrol. Sin. 2014, 30, 2481-2494. (In Chinese with English Abstract).

79. Guo, L.N.; Goldfarb, R.J.; Wang, Z.L.; Li, R.H.; Chen, B.H.; Li, J.L. A comparison of Jiaojia-and Linglong-type gold deposit ore-forming fluids: Do they differ? Ore Geol. Rev. 2017, 88, 511-533. [CrossRef]

80. Yang, L.Q.; Deng, J.; Guo, L.N.; Wang, Z.L.; Li, X.Z.; Li, J.L. Origin and evolution of ore fluid, and gold deposition processes at the giant Taishang gold deposit, Jiaodong Peninsula, eastern China. Ore Geol. Rev. 2016, 72, 585-602. [CrossRef]

81. Muntean, J.L.; Cline, J.S.; Simon, A.C.; Longo, A.A. Magmatic-hydrothermal origin of Nevada's Carlin-type gold deposits. Nat. Geosci. 2011, 4, 122-127. [CrossRef]

82. Makoundi, C.; Zaw, K.; Large, R.R.; Meffre, S.; Lai, C.K.; Hoe, T.G. Geology, geochemistry and metallogenesis of the Selinsing gold deposit, central Malaysia. Gondwana Res. 2014, 26, 241-261. [CrossRef]

83. Deng, J.; Wang, Q.F.; Li, G.J.; Zhao, Y. Structural control and genesis of the Oligocene Zhenyuan orogenic gold deposit, SW China. Ore Geol. Rev. 2015, 65, 42-54. [CrossRef]

84. Deng, J.; Yang, L.Q.; Li, R.H.; Groves, D.I.; Santosh, M.; Wang, Z.L.; Sai, S.X.; Wang, S.R. Regional structural control on the distribution of world-class gold deposits: An overview from the giant Jiaodong Gold Province, China. Geol. J. 2018, 1-14. [CrossRef]

85. Deng, J.; Wang, C.M.; Bagas, L.; Santosh, M.; Yao, E. Crustal architecture and metallogenesis in the south-eastern North China Craton. Earth-Sci. Rev. 2018, 182, 251-272. [CrossRef]

86. Gebre-Mariam, M.; Groves, D.I.; Mcnaughton, N.J.; Mikucki, E.J.; Vearncombe, J.R. Archaean Au-Ag mineralisation at Racetrack, near Kalgoorlie, Western Australia: A high crustal-level expression of the Archaean composite lode-gold system. Miner. Depos. 1993, 28, 375-387. [CrossRef]

87. Groves, D.I.; Goldfarb, R.J.; Gebre-Mariam, M.; Hagemann, S.G.; Robert, F. Orogenic gold deposits: A proposed classification in the context of their crustal distribution and relationship to other gold deposit types. Ore Geol. Rev. 1998, 13, 7-27. [CrossRef]

88. Yang, L.Q.; Deng, J.; Wang, Z.L.; Guo, L.N.; Li, R.H.; Groves, D.I.; Danyushevskiy, L.; Zhang, C.; Zheng, X.L.; Zhao, H. Relationships between gold and pyrite at the Xincheng gold deposit, Jiaodong Peninsula, China: Implications for gold source and deposition in a brittle epizonal environment. Econ. Geol. 2016, 111, 105-126. [CrossRef]

89. Yang, L.Q.; Guo, L.N.; Wang, Z.L.; Zhao, R.X.; Song, M.C.; Zheng, X.L. Timing and mechanism of gold mineralization at the Wang'ershan gold deposit, Jiaodong Peninsula, eastern China. Ore Geol. Rev. 2017, 88, 491-510. [CrossRef]

(C) 2018 by the authors. Licensee MDPI, Basel, Switzerland. This article is an open access article distributed under the terms and conditions of the Creative Commons Attribution (CC BY) license (http:// creativecommons.org/licenses/by/4.0/). 